\title{
霊長類マカク属の大臼霜についての比較形態学的研究
}

九州歯科大学口腔解剖学第 1 講座（指導 : 山田 博教授)

谷口英昭

昭和 58 年 10 月 20 日受付

\section{Comparative Morphological Study of Molar Teeth of Macaca Genus of Primates}

\author{
Hideaki Taniguchi \\ First Department of Oral Anatomy (Director : Prof. Hiroshi Yamada) \\ Kyushu Dental College, Kitakyushu, Japan
}

Morphological studies of teeth of primates are very important for elucidation of phylogenic aspects of teeth of mammals. Among the primates, catarrhina, in particular, along with anthropoid has a dental formula similar to human's and presents morphological similarities.

For this study, rhesus monkeys, Japanese monkeys, and crab-eating monkeys of Macaca genus were selected and the crowns of the upper and lower molars were measured. The measurements were then compared with those of other primates and examined from a morphological standpoint.

The results were as follows :

1. Mesiodistal diameters, buccolingual diameters, and occlusal surface areas of the upper and lower first molars were significantly larger in Japanese monkeys than in crab-eating monkeys or rhesus monkeys. A similar tendency was seen for the second and third molars.

2. Among the primates, the sizes of the teeth of Macaca genus fell within the same range of the teeth of other catarrhina, and were larger than platyrrhina's and smaller than hominidae's.

3. The crown indexes for the upper and lower molars of Macaca genus were all larger than 100 and the mesiodistal diameters were larger than buccolingual diameters. The mesiodistal diameters for the lower jaw in particular were significantly larger than those for the upper jaw. Catarrhina showed larger indexes as compared with platyrrhina and hominidae. In contrast with catarrhina, most species of platyrrhina and hominidae showed indexes less than 100 especially for the upper jaw, and the buccolingual diameters were larger than the mesiodistal diameters.

4. Examination by the distal crown diminution index of the difference between the mesio-buccolingual diameter and disto-buccolingual diameter shows that the mesial side 
is generally larger than the distal side. The diminution rates of the distal side were more marked for the upper jaw than for the lower jaw. The more posteriorly positioned a tooth was, the greater the diminution rate was, as the third molar was greater in value than the second molar, which in turn was greater than the first molar. The diminution indexes for Macaca genus tended to be slightly larger than those for other primates although the differences were small.

5. In Macaca genus, second and third molars were larger in size as compared with first molar. However, there was some difference between the upper and lower jaw in the trend for the teeth on the distal side to increase their size. In the upper jaw, although second molars were larger than first molars, there was little difference between second and third molars. In crab-eating monkeys, third molars were more diminished in size than second molars. In the lower jaw successive increase in size was seen from first molar to second molar and to third molar.

6. Although the teeth positioned posteriorly to first molar increase thier size in Macaca genus, the teeth on the posterior side in anthropoid and hominidae tend to diminish. This tendency is quite marked especially in human. In other words, regression of molars from the posterior side is seen in hominidae, while such occurrence has not yet been recognized in Macaca genus.

\section{緒}

霊長類の歯についての形態学的研究は，哺乳類の雬の 系統発生学的問題を解明していく上で, きわめて重要な 意味をもっているものである，霊長類のなかでも特に狭 鼻猿類は類人猿と共に，ヒ上と同様の歯式を有し，形態 的にも類似した点も認如られる。

従って現生霊長類の歯についての形態学的研究も多く

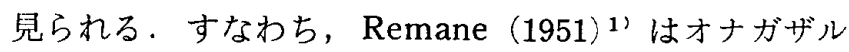

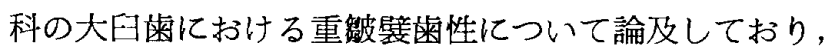
佐伯 $(1961)^{2}{ }^{2}{ }^{3}$ はサルの大曰苗菌冠形態についての研 究を行っている. Frisch (1963) ${ }^{4)}$ は手長猿の犬䨑の大 きさについての性差を，Saheki (1966) ${ }^{5)}$ はニホンザル の苗牙形態について，中川 $\left.(1971)^{6}\right)$ はカニクイザルの 歯冠形態を， Lauer $(1975)^{7}$ はキイロヒヒとゴリラに おける性的二型性と変異の限界について述へておうり，ま た瀬戸口 $(1982)^{82} \quad(1983)^{93}$ はホエザルの祖先スタート ニア，ならびにリスザルの䍘列に見られる性的二型につ いて述べている．馬場（1979）101はニホンザルの菌冠に ついて，また花田（1979）111はアカゲザルの乳歯の形態 についての研究を行っている.

畫長類は原猿，新世界ザル(㕕鼻猿)，旧世界ザル(狭 㑭猿）および類人猿に大別される。このうち旧世界ザル
の菌式はすべて I $\frac{2}{2} \mathrm{C} \frac{1}{1} \mathrm{P} \frac{2}{2} \mathrm{M} \frac{3}{3}=32$ と全くヒトと同 様である．旧世界ザルすなわちオナガザル科（cercopithecids) にはオナガザル属 (cercopithecus) やマカ ク属 (macaca)，七七属（papio）など，13の属江分類 されている．またマカク属には約12の種類があるといわ れている12).

今回, 著者はこのマカク属のなかで, アカゲザル, 二 ホンザルおよびカニクイザルの 3 種類について，それら

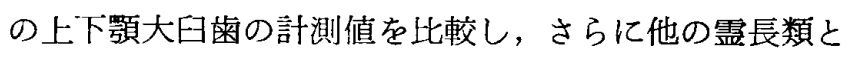
の間の差異を検討してみた。その結果，今回調査の対象 とした 3 種のサルのマカク属のなかに扔ける形態的位置 づけ，あるいは他の狭鼻猿類および治鼻猿領ならび類 人猿やヒトとの間における相異をみるととができ，甚だ 興味ある問題を提議し得たと考えるので，その概要を報 告する.

\section{調查材料と調查方法}

今回の調查に使用した資料はアカゲザル（Macaca mulatta), 二ホンザル (Macaca fuscata), カニクイザ ル (Macaca irus) の上下類各大曰歯で, これらはいず れも本学口腔解剖学第 1 講座所蔵のものである.

なお，各菌の調查総数は表 1 のでとくである．例数が 
Table 1 Investigation materials

\begin{tabular}{c|c|c|c}
\hline & $\begin{array}{c}\text { Macaca } \\
\text { mulatta }\end{array}$ & $\begin{array}{l}\text { Macaca } \\
\text { fuscata }\end{array}$ & $\begin{array}{l}\text { Macaca } \\
\text { irus }\end{array}$ \\
\hline$\underline{\mathrm{M}_{1}}$ & 55 & 43 & 82 \\
$\overline{\mathrm{M}_{1}}$ & 60 & 46 & 76 \\
$\underline{\mathrm{M}_{2}}$ & 6 & 38 & 74 \\
$\overline{\mathrm{M}_{2}}$ & 14 & 33 & 72 \\
$\underline{\mathrm{M}_{3}}$ & & 30 & 27 \\
$\overline{\mathrm{M}_{3}}$ & & 27 & 30 \\
\hline
\end{tabular}

少ないものもあるが特にアカゲザルの $\mathrm{M}_{3}$ は資料がきわ めて少数なので，除外した。乙れらの各匊はいずれも雌 雄ならびに左右側は合して取り扱っている。

計測は歯冠の近遠心径之煩舌径について行い，煩舌径 は近心煩舌径と遠心煩舌径をそれぞれ別個に計測した。 つぎに近心煩舌径を 100 とした場合の近遠心径の割合を 商冠示数として算出した．また近遠心径 $\times$ 近心煩舌径の 值をもって咬合面面積とした，咬合面における煩舌径に ついて近心煩舌径を 100 とした場合の遠心煩舌径の割合 を煩舌径近遠心示数として算出した。.さらに近, 遠心煩 舌径の差を求め, この值を近心煩舌径で除して 100 倍し たものを菌冠遠心側縮小示数とした。

歯冠の近遠心佳, 近心煩舌径および咬合面面積につい ては上下頡それぞれの第 1 大臼菌を 100 として，第 2 お よび第 3 大臼雨がどのような大きさの関係にあるのかを 各項目ごとに大曰曾示数として算出した.

計測は藤田 $(1949)^{13}{ }^{13}$ のヒトの歯の計測規準に従って 行い, 計測には $1 / 20 \mathrm{~mm}$ 副尺付きのノギスを使用し
た。なお，平均租 $(\overline{\mathrm{X}})$ ならびに標準偏差 $(\mathrm{SD})$ を算出 し, 二つの平均値間の差の検定は $\mathrm{t}$ 検定により $5 \%$ の水 準でもって有意の差があるとした。

\section{調 查 成}

\section{A 歯冠近遠心径}

\section{1 第 1 大曰雬}

上頱および下顎第 1 大曰霜の雪冠近遠心径は表 2 亿示 すでとくである．上下顎ともニホンザルが最も大きく， 以下カニクイザル，アカゲザルの順となっている．特に ニホンザルは他の 2 種に比べて著しく大きい．カニクイ ザルとアカゲザルとの間では上顎には有意の差がある が，下堮页では差はない，つぎに上下顎間においては，僅 かにニホンザルで差が䐂められる程度である。

\section{2 第 2 大田菌}

第 2 大曰霜の歯冠近遠心径㟍 3 のごとく，第 1 大曰 雪の場合と同样に二ホンザルが他の 2 種に比べて著しく 大きく,カニクイザルとアカゲザルとの間にはほとんど 差はない．また上顎と下顥の第 2 大臼菌の間にはほとん ど差は認められない。

\section{3 第 3 大臼菌}

第 3 大曰菌では表 4 のごとくニホンザルがカニクイザ ルよりも著明に大きく，また上頱と下須の菌の間にも著 しい差が認められ，下顎が大きい。

\section{B 近心煩舌径}

\section{1 第 1 大臼歯}

第 1 大曰雬の近心煩舌径は表 5 に示すでとく， 3 種と もに上額が下顎よりも著しく大きい，また各種属間では ニホンザルが他の 2 種よりも有意の差を示して大きく， カニクイザルとアカゲザルとでは, 上顎は後者が, 下䋶

Table 2

The mesiodistal diameter of the first molars of Macaca genus

\begin{tabular}{|c|c|c|c|c|c|c|c|c|c|c|}
\hline & & \multicolumn{3}{|c|}{ A } & \multicolumn{3}{|c|}{ B } & \multicolumn{3}{|c|}{$\mathrm{C}$} \\
\hline & & $\mathbf{N}$ & $\bar{X}(\mathrm{~mm})$ & S D & $\mathrm{N}$ & $\overline{\mathrm{X}}(\mathrm{mm})$ & S D & $\mathrm{N}$ & $\bar{X}(\mathrm{~mm})$ & S D \\
\hline & $\underline{\mathbf{M}_{1}}$ & 55 & 6.85 & 0.41 & 43 & 7.96 & 0.62 & 82 & 7.06 & 0.44 \\
\hline & $\overline{\mathbf{M}_{1}}$ & 60 & 6.95 & 0.34 & 46 & 7.57 & 0.79 & 76 & 7.00 & 0.51 \\
\hline & diff. & & -0.10 & & & 0.39 & & & 0.06 & \\
\hline $\mathrm{M}_{1}-\overline{\mathrm{M}_{1}}$ & ts & & 1.41 & & & 2.44 & & & 0.79 & \\
\hline & sig. & & & & & * & & & & \\
\hline
\end{tabular}

A : Macaca mulatta

B : Macaca fuscata

C : Macaca irus

Sig : $\left\{\begin{array}{l}{ }^{*}-\text { Significant at the } 5 \% \text { level confidence } \\ * * \text { Significant at the } 1 \% \text { level confidence }\end{array}\right.$ 
The mesiodistal diameter of the second molars of Macaca genus

\begin{tabular}{|c|c|c|c|c|c|c|c|c|c|c|}
\hline \multirow{2}{*}{\multicolumn{2}{|c|}{ 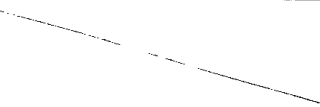 }} & \multicolumn{3}{|c|}{ A } & \multicolumn{3}{|c|}{ B } & \multicolumn{3}{|c|}{$\mathrm{C}$} \\
\hline & & $\mathrm{N}$ & $\overline{\mathrm{X}}(\mathrm{mm})$ & S D & $\mathrm{N}$ & $\overline{\mathrm{X}}(\mathrm{mm})$ & S D & $\mathrm{N}$ & $\overline{\mathrm{X}}(\mathrm{mm})$ & S D \\
\hline & $\underline{\mathrm{M}_{2}}$ & 6 & 7.73 & 0.38 & 38 & 9.09 & 1.13 & 74 & 7.79 & 0.44 \\
\hline & $\overline{\mathrm{M}_{2}}$ & 14 & 7.62 & 0.46 & 33 & 8.85 & 1.14 & 72 & 7.81 & 0.50 \\
\hline \multirow{3}{*}{$\underline{\mathrm{M}_{2}}-\overline{\mathrm{M}}_{2}$} & diff. & \multicolumn{3}{|c|}{0.11} & \multicolumn{3}{|c|}{0.24} & \multicolumn{3}{|c|}{-0.02} \\
\hline & ts & \multirow{2}{*}{\multicolumn{3}{|c|}{0.52}} & \multirow{2}{*}{\multicolumn{3}{|c|}{0.89}} & \multirow{2}{*}{\multicolumn{3}{|c|}{0.26}} \\
\hline & Sig. & & & & & & & & & \\
\hline
\end{tabular}

Table 4 The mesiodistal diameter of the third molars of Macaca genus

\begin{tabular}{|c|c|c|c|c|c|c|c|}
\hline & & \multicolumn{3}{|c|}{ B } & \multicolumn{3}{|c|}{$\mathrm{C}$} \\
\hline & & $\mathrm{N}$ & $\overline{\mathrm{X}}(\mathrm{mm})$ & S D & $\mathrm{N}$ & $\overline{\mathrm{X}}(\mathrm{mm})$ & S D \\
\hline & $\underline{\mathrm{M}}_{3}{ }^{\circ}$ & 30 & 9.03 & 1.14 & 27 & 7.49 & 0.42 \\
\hline & $\overline{\mathrm{M}_{3}}$ & 27 & 11.19 & 1.42 & 30 & 9.05 & 0.63 \\
\hline \multirow{3}{*}{$\underline{\mathrm{M}_{3}}-\overline{\mathrm{M}_{3}}$} & diff. & & -2.16 & & & -1.56 & \\
\hline & ts & & 6.36 & & & 10.89 & \\
\hline & Sig. & & $* *$ & & & $* *$ & \\
\hline
\end{tabular}

Table 5

The mesial buccolingual diameter of the first molars of Macaca genus

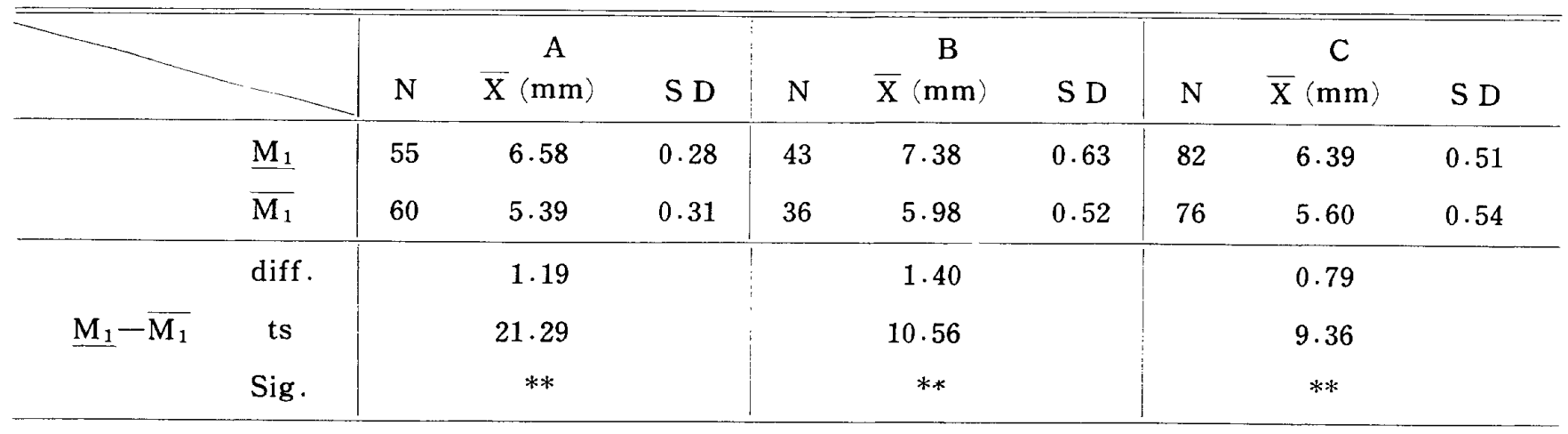

は前者が有意に大である。

\section{2 第 2 大曰歯}

第 2 大曰西もほぼ第 1 大曰歯と同じような傾向で，表

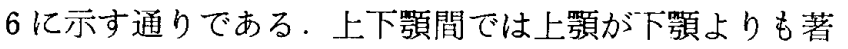
明に大きく，３種間では上下顎とも二ホンザルが他より も著しく大きく，ついでカニクイザル，アカゲザルの順 である。

\section{3 第 3 大曰菌}

第 3 大曰米については表 7 に示す通りで，上顥が有意 の差を示して下顎よりも大きい。またニホンザルは，カ
ニクイザルに比べて有意差を示して大である.

\section{C 遠心煩舌径}

1 第 1 大臼菌

表 8 に見られるごとく，近心煩舌径の場合とほとんど 同様の傾向である．すなわち上顎が下顎よりも著しく大 きく， 3 種間ではニホンザルが他よりも著明に大きい．

2 第 2 大曰歯

表 9 のごとく，上顎が下䫕よりも著しく大きく，二小 ンザルは他の 2 種に比べて著明に大である.なおカニク イザルとアカゲザルでは，下䫇のみに有意差が認めら 
Table 6

The mesial buccolingual diameter of the second molars of Macaca genus

\begin{tabular}{|c|c|c|c|c|c|c|c|c|c|c|}
\hline & & \multicolumn{3}{|c|}{ A } & \multicolumn{3}{|c|}{ B } & \multicolumn{3}{|c|}{$\mathrm{C}$} \\
\hline & & $\mathrm{N}$ & $\overline{\mathrm{X}}(\mathrm{mm})$ & S D & $\mathrm{N}$ & $\overline{\mathrm{X}}(\mathrm{mm})$ & S D & $\mathrm{N}$ & $\bar{X}(\mathrm{~mm})$ & S D \\
\hline & $\underline{\mathrm{M}_{2}}$ & 6 & 7.13 & 0.29 & 38 & 8.67 & 0.89 & 74 & 7.31 & 0.68 \\
\hline & $\overline{\mathrm{M}_{2}}$ & 14 & 6.05 & 0.33 & 33 & 7.09 & 0.75 & 72 & 6.68 & 0.58 \\
\hline \multirow{3}{*}{$\underline{\mathrm{M}_{2}}-\overline{\mathrm{M}_{2}}$} & diff. & \multicolumn{3}{|c|}{1.08} & \multicolumn{3}{|c|}{1.58} & \multicolumn{3}{|c|}{0.63} \\
\hline & ts & \multicolumn{3}{|c|}{7.13} & \multicolumn{3}{|c|}{8.00} & \multicolumn{3}{|c|}{5.95} \\
\hline & Sig. & \multicolumn{3}{|c|}{$* *$} & \multicolumn{3}{|c|}{$* *$} & \multicolumn{3}{|c|}{$* *$} \\
\hline
\end{tabular}

Table 7 The mesial buccolingual diameter of the third molars of Macaca genus

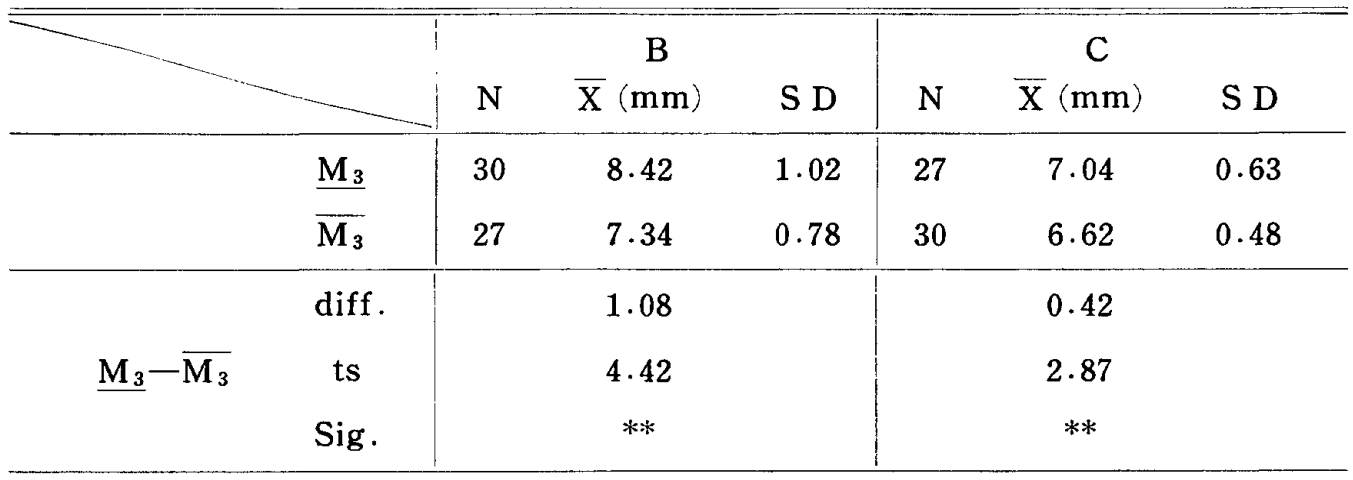

Table 8 The distal buccolingual diameter of the first molars of Macaca genus

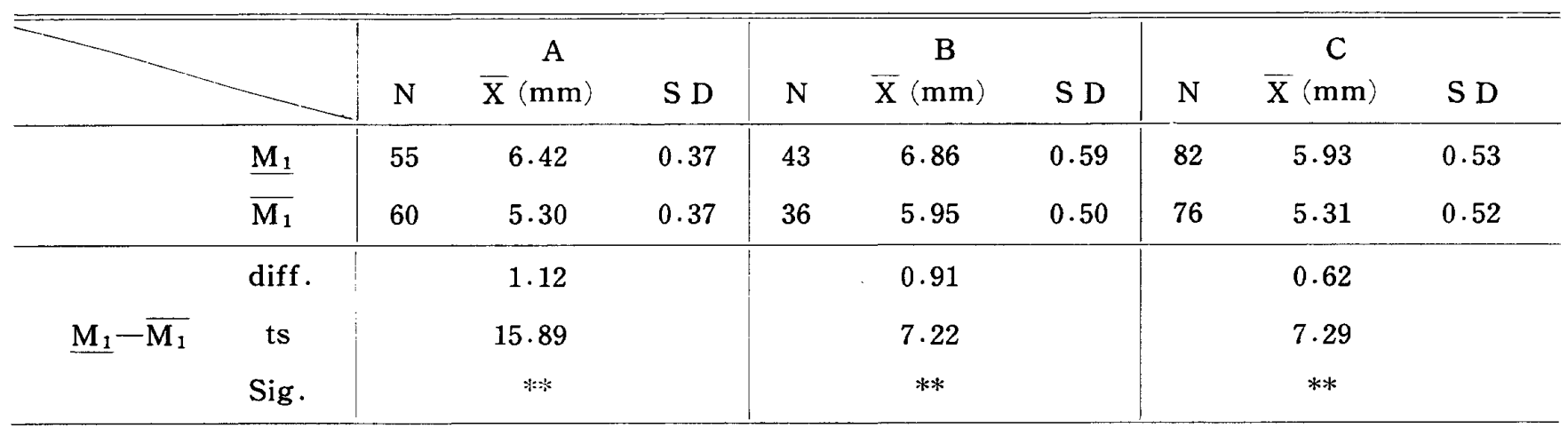

Table 9

The distal buccolingual diameter of the second molars of Macaca genus

\begin{tabular}{|c|c|c|c|c|c|c|c|c|c|c|}
\hline & & \multicolumn{3}{|c|}{ A } & \multicolumn{3}{|c|}{ B } & \multicolumn{3}{|c|}{$\mathrm{C}$} \\
\hline & & $\mathrm{N}$ & $\overline{\mathrm{X}}(\mathrm{mm})$ & S D & $\mathrm{N}$ & $\bar{X}(\mathrm{~mm})$ & S D & $\mathrm{N}$ & $\bar{X}(\mathrm{~mm})$ & S D \\
\hline & $\underline{\mathrm{M}_{2}}$ & 6 & 6.37 & 0.48 & 38 & 7.75 & 0.71 & 74 & 6.52 & 0.77 \\
\hline & $\overline{\mathrm{M}_{2}}$ & 14 & 5.59 & 0.38 & 33 & 6.85 & 0.78 & 72 & 6.12 & 0.62 \\
\hline \multirow{3}{*}{$\underline{\mathbf{M}_{2}}-\overline{\mathbf{M}_{2}}$} & diff. & \multicolumn{3}{|c|}{0.78} & \multicolumn{3}{|c|}{0.90} & \multicolumn{3}{|c|}{0.40} \\
\hline & ts & \multicolumn{3}{|c|}{3.90} & \multicolumn{3}{|c|}{5.04} & \multicolumn{3}{|c|}{3.46} \\
\hline & Sig. & \multicolumn{3}{|c|}{$* *$} & \multicolumn{3}{|c|}{$* *$} & \multicolumn{3}{|c|}{$* *$} \\
\hline
\end{tabular}


れ，カニクイザルが大である.

\section{3 第 3 大臼歯}

第 3 大臼歯は表10亿示す通りで，乙の䨑では，上顎が 下頂よりも大であるが，有意の差はない。ニホンザルは カニクイザルに比べて，明らかに大きい。

D 菌冠示数

1 第 1 大臼歯

表11に示すでとく，上額ではカニクイザルが最も大き い数值を示し，煩舌径に対して近遠心径が相対的に大き いことを示唆している．以下二ホンザル，アカゲザルの
順に小さい数値となっている。一顎では逆にアカゲザル が最も大きい数值を示し，以下二ホンザル，カニクイザ ルの順となっている。しかし 3 種属とも，上顎よりも下 顎の方が示数值は有意の差をもって大きく，下顎が上顎 に比へ煩舌径に対する近遠心径の大なるてとを示してい る。

\section{2 第 2 大曰雬}

第 2 大日歯の歯冠示数は表 12 のごとく，上頱では 3 種 間に差はなく，下顎では第 1 大囦歯と同様にアカゲザ ル，ニホンザル，カニクイザルの順で，特に前二者とカ

Table 10 The distal buccolingual diameter of the third molars of Macaca genus

\begin{tabular}{|c|c|c|c|c|c|c|c|}
\hline & \multicolumn{3}{|c|}{ B } & \multicolumn{3}{|c|}{$\mathrm{C}$} \\
\hline & & $\mathrm{N}$ & $\bar{X}(\mathrm{~mm})$ & $\mathrm{S} \mathrm{D}$ & $\mathrm{N}$ & $\overline{\mathrm{X}}(\mathrm{mm})$ & S D \\
\hline & $\underline{\mathrm{M}_{3}}$ & 30 & 7.03 & 0.80 & 27 & 6.06 & 0.56 \\
\hline & $\overline{M_{3}}$ & 27 & 6.63 & 0.72 & 30 & 5.92 & 0.52 \\
\hline \multirow{3}{*}{$\underline{\mathrm{M}_{3}}-\overline{\mathrm{M}_{3}}$} & diff. & \multirow{3}{*}{\multicolumn{3}{|c|}{$\begin{array}{l}0.40 \\
1.99\end{array}$}} & \multicolumn{3}{|c|}{0.14} \\
\hline & ts & & & & \multirow{2}{*}{\multicolumn{3}{|c|}{0.98}} \\
\hline & Sig. & & & & & & \\
\hline
\end{tabular}

Table 11

The crown index of the first molars of Macaca genus

\begin{tabular}{|c|c|c|c|c|c|c|c|c|c|c|}
\hline & & \multicolumn{3}{|c|}{ A } & \multicolumn{3}{|c|}{$\mathrm{B}$} & \multicolumn{3}{|c|}{$\mathrm{C}$} \\
\hline & & $\mathrm{N}$ & $\bar{X}$ & S D & $\mathrm{N}$ & $\bar{X}$ & S D & $\mathrm{N}$ & $\bar{X}$ & S D \\
\hline & $\mathrm{M}_{1}$ & 55 & 104.09 & 5.15 & 43 & 106.48 & 6.41 & 82 & 111.29 & 6.29 \\
\hline & $\overline{\mathrm{M}_{1}}$ & 60 & $131 \cdot 41$ & 5.71 & 36 & 126.61 & 7.42 & 76 & 125.30 & 8.42 \\
\hline \multirow{3}{*}{$\underline{\mathrm{M}_{1}}-\overline{\mathrm{M}_{1}}$} & diff. & & $-27 \cdot 32$ & & & -20.13 & & & -14.01 & \\
\hline & ts & & 26.81 & & & 12.91 & & & 11.90 & \\
\hline & Sig. & & $* *$ & & & $* *$ & & & $* *$ & \\
\hline
\end{tabular}

Table 12

The crown index of the second molars of Macaca genus

\begin{tabular}{|c|c|c|c|c|c|c|c|c|c|c|}
\hline \multirow{2}{*}{\multicolumn{2}{|c|}{ 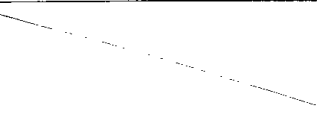 }} & \multicolumn{3}{|c|}{ A } & \multicolumn{3}{|c|}{ B } & \multicolumn{3}{|c|}{$\mathrm{C}$} \\
\hline & & $\mathrm{N}$ & $\overline{\mathrm{X}}$ & S D & $\mathrm{N}$ & $\bar{X}$ & S D & $\mathrm{N}$ & $\mathrm{X}$ & S D \\
\hline & $\underline{\mathrm{M}_{2}}$ & 6 & 108.42 & 3.66 & 38 & 105.11 & 6.33 & 74 & 107.87 & 8.76 \\
\hline & $\overline{\mathrm{M}_{2}}$ & 14 & 127.29 & 3.85 & 33 & $124 \cdot 36$ & 7.83 & 72 & 118.00 & 9.53 \\
\hline \multirow{3}{*}{$\underline{\mathrm{M}_{2}}-\overline{\mathrm{M}_{2}}$} & diff. & & -18.87 & & & -19.25 & & & $-10 \cdot 13$ & \\
\hline & ts & & 10.18 & & & 11.44 & & & 6.69 & \\
\hline & Sig. & & $* *$ & & & ** & & & $* *$ & \\
\hline
\end{tabular}


ニクイザルとの間には有意の差が認められた。また上下

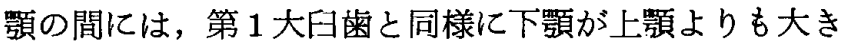
い数值を示していた。

3 第 3 大罩菌

第 3 大臼雨はニホンザルとカニクイザルのみである が，表13のごとく，上顎では両者間に差はなく，下頇で はニホンザルが著明に大きな数值を示していた．また上 下額間では，下額が上頢に比べ，有意の差を示して大き かーカー

\section{E 咬合面面積}

1 第 1 大日來
近心煩舌径と近遠心径の積をもって，咬合面面積と し，一応歯冠の全体的な大きさの目安としたものであ る．その成䋶は表14に示すごとく，上下頡とも最も大き いのはニホンザルで，以下カニクイザル，アカゲザルの 順となっている．しかしカニクイザルとアカゲザルとは それほど大きな差はなく，特に上顎では有意の差はな い。また上下䝷間ではいずれも有意差をもって上頧が大 きい。

\section{2 第 2 大曰歯}

第 2 大曰歯も第 1 大曰菌と 同じく，表15に示すごと く，ニホンザルが最も大きく，以下カニクイザル，アカ

Table 13 The crown index of the third molars of Macaca genus

\begin{tabular}{|c|c|c|c|c|c|c|c|}
\hline & & \multicolumn{3}{|c|}{ B } & \multicolumn{3}{|c|}{$\mathrm{C}$} \\
\hline & & $\mathrm{N}$ & $\overline{\mathrm{X}}$ & S D & $\mathrm{N}$ & $\bar{X}$ & S D \\
\hline & $\underline{\mathrm{M}_{3}}$ & 30 & 108.83 & 4.37 & 27 & 107.63 & 9.09 \\
\hline & $\overline{\mathrm{M}_{3}}$ & 27 & 153.37 & 6.49 & 30 & 136.83 & 11.65 \\
\hline & $\operatorname{diff}$. & & -44.54 & & & -29.20 & \\
\hline \multirow[t]{2}{*}{$\underline{\mathrm{M}_{3}}-\overline{\mathrm{M}_{3}}$} & ts & & 30.64 & & & 10.47 & \\
\hline & Sig. & & $* *$ & & & $* *$ & \\
\hline
\end{tabular}

Table 14 The occlusal surface area of the first molars of Macaca genus

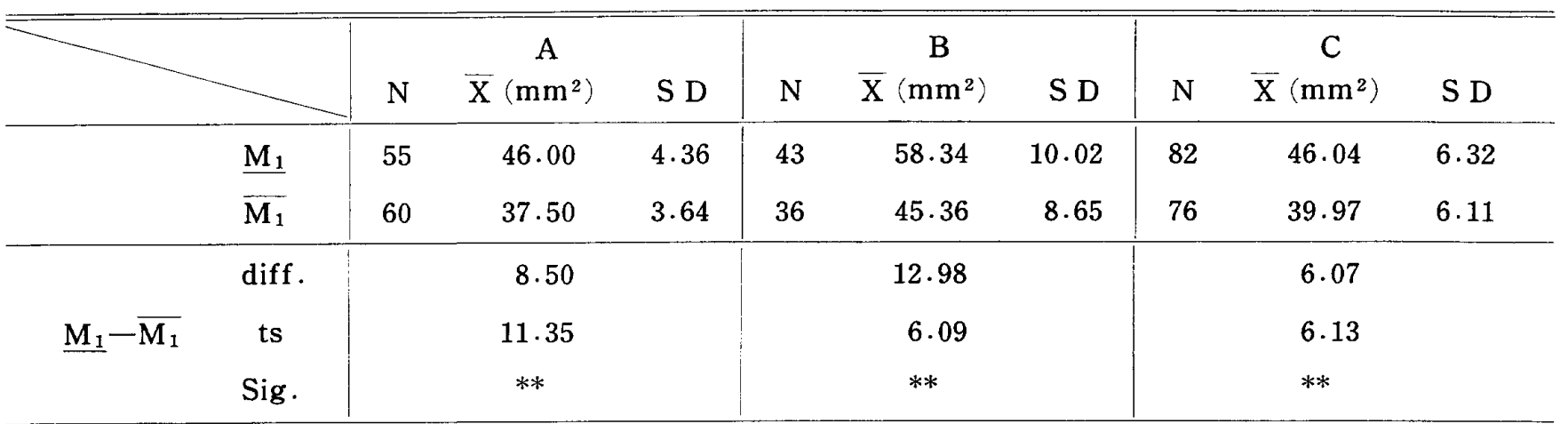

Table 15 The occlusal surface area of the second molars of Macaca genus

\begin{tabular}{|c|c|c|c|c|c|c|c|c|c|c|}
\hline & & \multicolumn{3}{|c|}{ A } & \multicolumn{3}{|c|}{ B } & \multicolumn{3}{|c|}{$\mathrm{C}$} \\
\hline & & $\mathrm{N}$ & $\overline{\mathrm{X}}\left(\mathrm{mm}^{2}\right)$ & S D & $\mathrm{N}$ & $\overline{\mathrm{X}}\left(\mathrm{mm}^{2}\right)$ & S D & $\mathrm{N}$ & $\overline{\mathrm{X}}\left(\mathrm{mm}^{2}\right)$ & S D \\
\hline & $\underline{\mathrm{M}_{2}}$ & 6 & 55.25 & 4.72 & 38 & 79.84 & 16.21 & 74 & 57.26 & 7.48 \\
\hline & $\overline{\mathrm{M}_{2}}$ & 14 & 47.29 & $4 \cdot 32$ & 33 & 63.61 & 13.21 & 72 & 52.24 & $7 \cdot 30$ \\
\hline \multirow{3}{*}{$\underline{\mathrm{M}_{2}}-\overline{\mathrm{M}_{2}}$} & $\operatorname{diff}$ & \multicolumn{3}{|c|}{7.96} & \multicolumn{3}{|c|}{16.23} & \multicolumn{3}{|c|}{5.02} \\
\hline & ts & \multicolumn{3}{|c|}{3.68} & \multicolumn{3}{|c|}{4.58} & \multicolumn{3}{|c|}{4.10} \\
\hline & Sig. & \multicolumn{3}{|c|}{$* *$} & \multicolumn{3}{|c|}{$* *$} & \multicolumn{3}{|c|}{$* *$} \\
\hline
\end{tabular}


ゲザルの順である．しかし，カニクイザルとアカゲザル との間では差は小さく，特に上㖽では有意の差は認めら

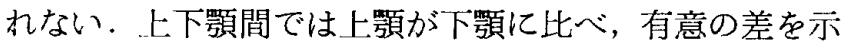
して大きい。

\section{3 第 3 大F疄}

表16に示すごとく，上下堮頁ともニホンザルがカニクイ ザルよりも著しく大きい，上下顎間では，第 1 および第

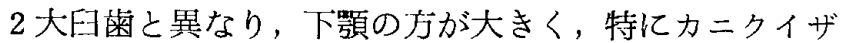

ルでは有意差をもって大きい。

\section{F 近心煩舌径と遠心煩舌径との差}

\section{1 第 1 大曰歯}

近心煩舌径と遠心煩舌佳との差を求めたものである が，表17に示すごとく，3 種とも近心煩舌径が，遠心煩

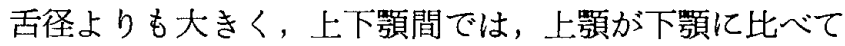
その差は著しく大きい， 3 種間について比較してみる 上，上䕱においてはニホンザルが最も差が大きく，つい

Table 16 The occlusal surface area of the third molars of Macaca genus

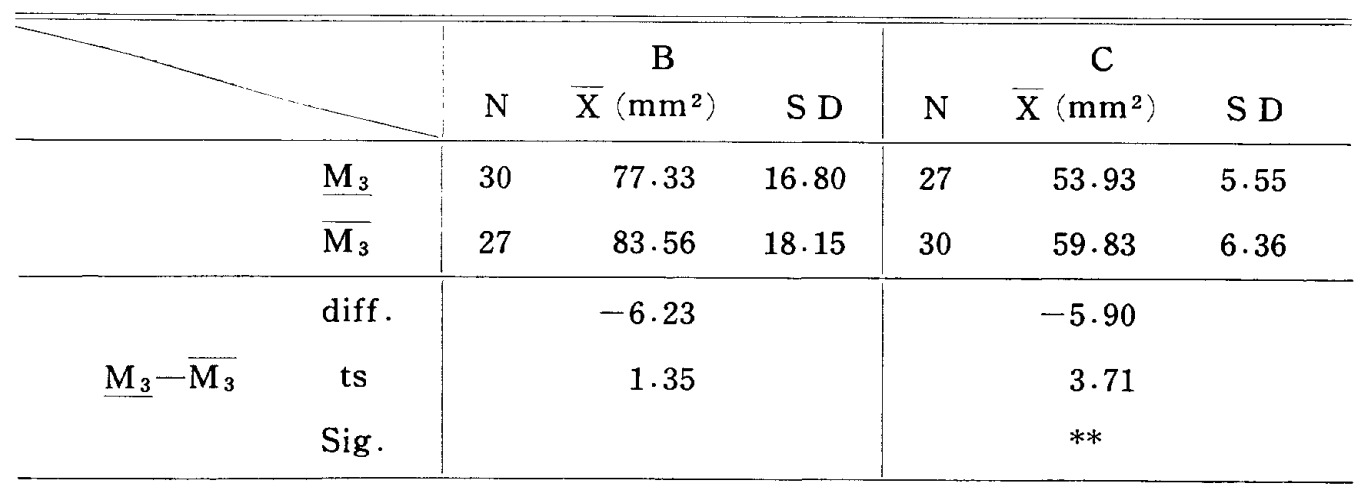

Table 17 The difference between mesial and distal buccolingual diameter of the first molars of Macaca genus

\begin{tabular}{|c|c|c|c|c|c|c|c|c|c|c|}
\hline & & \multicolumn{3}{|c|}{ A } & \multicolumn{3}{|c|}{ B } & \multicolumn{3}{|c|}{$\mathrm{C}$} \\
\hline & & $\mathrm{N}$ & $\bar{X}(\mathrm{~mm})$ & S D & $\mathrm{N}$ & $\overline{\mathrm{X}}(\mathrm{mm})$ & S D & $\mathrm{N}$ & $\overline{\mathrm{X}}(\mathrm{mm})$ & S D \\
\hline & $\underline{\mathrm{M}_{1}}$ & 55 & 0.21 & 0.19 & 43 & 0.50 & 0.21 & 82 & 0.47 & 0.22 \\
\hline & $\overline{\mathrm{M}_{1}}$ & 60 & 0.07 & 0.18 & 36 & 0.01 & 0.21 & 76 & 0.27 & 0.22 \\
\hline \multirow{3}{*}{$\underline{\mathrm{M}_{1}}-\overline{\mathrm{M}_{1}}$} & $\operatorname{diff}$ & & 0.14 & & & 0.49 & & & 0.20 & \\
\hline & ts & & 3.96 & & & 10.12 & & & 5.61 & \\
\hline & Sig. & & $* *$ & & & $* *$ & & & $* *$ & \\
\hline
\end{tabular}

Table 18 The difference between mesial and distal buccolingual diameter of the second molars of Macaca genus

\begin{tabular}{|c|c|c|c|c|c|c|c|c|c|c|}
\hline & & \multicolumn{3}{|c|}{ A } & \multicolumn{3}{|c|}{ B } & \multicolumn{3}{|c|}{$\mathrm{C}$} \\
\hline & & $\mathrm{N}$ & $\mathrm{X}(\mathrm{mm})$ & S D & $\mathrm{N}$ & $\bar{X}(\mathrm{~mm})$ & S D & $\mathrm{N}$ & $\bar{X}(\mathrm{~mm})$ & S D \\
\hline & $\underline{\mathrm{M}_{2}}$ & 6 & 0.77 & 0.40 & 38 & 0.89 & 0.32 & 74 & 0.75 & 0.36 \\
\hline & $\mathrm{M}_{2}$ & 14 & 0.41 & 0.33 & 33 & 0.28 & 0.30 & 72 & 0.54 & 0.37 \\
\hline \multirow{3}{*}{$\underline{\mathrm{M}_{2}}-\overline{\mathrm{M}_{2}}$} & diff. & \multicolumn{3}{|c|}{0.36} & \multicolumn{3}{|c|}{0.61} & \multicolumn{3}{|c|}{0.21} \\
\hline & ts & \multicolumn{3}{|c|}{2.11} & \multicolumn{3}{|c|}{8.26} & \multicolumn{3}{|c|}{3.53} \\
\hline & Sig & \multicolumn{3}{|c|}{$*$} & \multicolumn{3}{|c|}{$* *$} & \multicolumn{3}{|c|}{$* * ;$} \\
\hline
\end{tabular}


でカニクイザル，アカゲザルの順となっているが，二ホ ンザルとカニクイザルとの間には有意の差はない，下頼 においては差の最も大きいのはカニクイザルで，以下ア カゲザル，ニホンザルの順となっている．しかしアカゲ ザルとニホンザルとの間には有意の差はない。

\section{2 第 2 大的菌}

第 2 大曰䨑は近心煩舌径と遠心煩舌径の差がすべて第 1 大曰曾に比心゙て大きくなっている，表18に示すごと く，上顩が下顎に比べてその差は著しく大きく，また 3 種間の比較では，上㖽はニホンザル，アカゲザル，カニ クイザルの順に，下頼は逆にカニクイザル，アカゲザ ル，ニホンザルの順に差が小さくなっている。しかし， 有意の差が認められるのは上下須とも二ホンザルとカニ クイザルとの間のみである.

\section{3 第 3 大田菌}

第 3 大臼曾の成績は表19のでとくである，すなわち第 2 大曰菡に比べるとその差はさらに大となり，近心から 遠心向って第 1 よりも第 2 , 第 2 よりも第 3 大臼曾之 狭くなっていることがうかがえる。ここでも上顎が下影 よりも差は大きく，またニホンザルとカニクイザルを比
較すると，ニホンザルが大きいが，下堮頁ではほとんど差 はない・

\section{G 煩舌径近遠心示数}

\section{1 第 1 大四菌}

近心煩舌径を 100 とした場合の遠心煩舌径の割合を示 したもので，表20に第 1 大曰菌の成績を示している．上 䫟の方が下頻よりも小さい数值を示している． 3 種間で は上頻においてはカニクイザルが最も小さい数值を示 し，ついでニホンザル，アカゲザルと示数值は大きくな っているが, 特にアカゲザルは他の 2 種に此べて有意の 差を示している．下顎においてはカニクイザルが最も小 さい示数值で，ついでアカゲザル，二ホンザルの順に大 きい数值となっている.そしててれら 3 種間にはすべて 有意の差が認められる。

\section{2 第 2 大臼雨}

同じく第 2 大日匊の成績を示したのが表21である．や はり上顎が下䫟に比べて示数値は小さい。しかしアカゲ ザルでは有意の差は認められない，3 種間では上顎にお いては全く差はなく，下䫛においては二ホンザルが他の 2 種よりも大きい数值を示している.

Table 19 The difference between mesial and distal buccolingual diameter of the third molars of Macaca genus

\begin{tabular}{|c|c|c|c|c|c|c|c|}
\hline & & \multicolumn{3}{|c|}{$\mathrm{B}$} & \multicolumn{3}{|c|}{$\mathrm{C}$} \\
\hline & & $\mathrm{N}$ & $\overline{\mathrm{X}}(\mathrm{mm})$ & S D & $\mathrm{N}$ & $\overline{\mathrm{X}}(\mathrm{mm})$ & S D \\
\hline & $\underline{\mathrm{M}_{3}}$ & 30 & 1.35 & 0.48 & 27 & 0.91 & 0.40 \\
\hline & $\overline{M_{3}}$ & 27 & 0.70 & 0.36 & 30 & 0.68 & 0.37 \\
\hline \multirow{3}{*}{$\underline{\mathrm{M}_{3}}-\overline{\mathrm{M}_{3}}$} & $\operatorname{diff}$ & & 0.65 & & & 0.23 & \\
\hline & ts & & 5.70 & & & 2.29 & \\
\hline & Sig. & & $* *$ & & & $*$ & \\
\hline
\end{tabular}

Table 20 The mesiodistal index of buccolingual diameter of the first molars of Macaca genus

\begin{tabular}{|c|c|c|c|c|c|c|c|c|c|c|}
\hline & & \multicolumn{3}{|c|}{$\mathrm{A}$} & \multicolumn{3}{|c|}{ B } & \multicolumn{3}{|c|}{ C } \\
\hline & & $\mathrm{N}$ & $\bar{X}$ & S D & $\mathrm{N}$ & $\bar{X}$ & S D & $\mathrm{N}$ & $\bar{X}$ & S D \\
\hline & $\underline{\mathrm{M}_{1}}$ & 55 & 96.82 & 2.79 & 43 & 93.19 & 2.92 & 82 & 92.62 & 3.33 \\
\hline & $\overline{\mathrm{M}_{1}}$ & 60 & $98 \cdot 10$ & 3.36 & 36 & 99.72 & 3.50 & 76 & 95.10 & 3.44 \\
\hline \multirow{3}{*}{$\underline{\mathrm{M}_{1}}-\overline{\mathrm{M}_{1}}$} & diff. & & -1.28 & & & -6.53 & & & -2.48 & \\
\hline & ts & & 2.21 & & & 9.02 & & & 4.60 & \\
\hline & Sig. & & $*$ & & & $* *$ & & & $* *$ & \\
\hline
\end{tabular}


Table 21 The mesiodistal index of buccolingual diameter of the second molars of Macaca genus

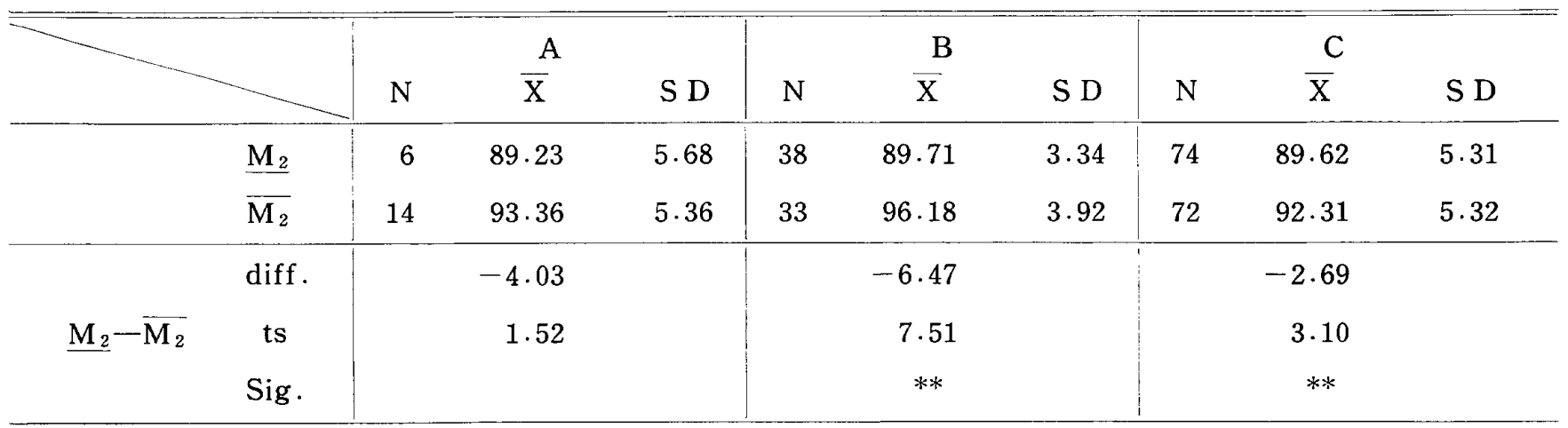

Table 22 The mesiodistal index of buccolingual diameter of the third molars of Macaca genus

\begin{tabular}{|c|c|c|c|c|c|c|c|}
\hline & & \multicolumn{3}{|c|}{ B } & \multicolumn{3}{|c|}{$\mathrm{C}$} \\
\hline & & $\mathrm{N}$ & $\overline{\mathrm{X}}$ & S D & $\mathrm{N}$ & $\bar{X}$ & S D \\
\hline & $\underline{\mathbf{M}_{3}}$ & 30 & 84.33 & 4.54 & 27 & 86.89 & 5.06 \\
\hline & $\overline{\mathrm{M}_{3}}$ & 27 & 90.41 & 5.07 & 30 & 90.33 & 4.87 \\
\hline \multirow{3}{*}{$\underline{\mathrm{M}_{3}}-\overline{\mathrm{M}_{3}}$} & $\operatorname{diff}$ & & -6.08 & & & -3.44 & \\
\hline & ts & & 4.78 & & & 2.61 & \\
\hline & Sig. & & $* * *$ & & & $* *$ & \\
\hline
\end{tabular}

Table 23 The diminution index of the distal buccolingual diameter of the first molars of Macaca genus

\begin{tabular}{|c|c|c|c|c|c|c|c|c|c|c|}
\hline & & \multicolumn{3}{|c|}{ A } & \multicolumn{3}{|c|}{ B } & \multicolumn{3}{|c|}{$\mathrm{C}$} \\
\hline & & $\mathrm{N}$ & $\overline{\mathrm{X}}$ & S D & $\mathrm{N}$ & $\overline{\mathrm{X}}$ & S D & $\mathrm{N}$ & $\overline{\mathrm{X}}$ & S D \\
\hline & $\underline{\mathrm{M}_{1}}$ & 55 & 3.17 & 2.79 & 43 & 6.84 & 2.91 & 82 & 7.47 & 3.47 \\
\hline & $\overline{\mathrm{M}_{1}}$ & 60 & 1.10 & 3.43 & 36 & -0.94 & 3.50 & 76 & 4.84 & 4.16 \\
\hline \multirow{3}{*}{$\underline{\mathrm{M}_{1}}-\overline{\mathrm{M}_{1}}$} & diff. & & 2.07 & & & 7.78 & & & 2.63 & \\
\hline & ts & & 3.52 & & & 10.76 & & & 4.32 & \\
\hline & Sig. & & $* *$ & & & $* *$ & & & $* *$ & \\
\hline
\end{tabular}

Table 24 The diminution index of the distal buccolingual diameter of the second molars of Macaca genus

\begin{tabular}{|c|c|c|c|c|c|c|c|c|c|c|}
\hline & & \multicolumn{3}{|c|}{ A } & \multicolumn{3}{|c|}{ B } & \multicolumn{3}{|c|}{$\mathrm{C}$} \\
\hline & & $\mathrm{N}$ & $\bar{x}$ & S D & $\mathrm{N}$ & $\overline{\mathrm{X}}$ & S D & $\mathrm{N}$ & $\overline{\mathrm{X}}$ & S D \\
\hline & $\underline{\mathrm{M}_{2}}$ & 6 & 10.77 & 5.68 & 38 & $10 \cdot 32$ & 3.08 & 74 & 10.28 & 5.04 \\
\hline & $\overline{\mathrm{M}_{2}}$ & 14 & 6.71 & 5.24 & 33 & 3.86 & 4.36 & 72 & 7.75 & 5.32 \\
\hline \multirow{3}{*}{$\underline{\mathrm{M}_{2}}-\overline{\mathrm{M}_{2}}$} & diff. & \multirow{3}{*}{\multicolumn{3}{|c|}{$\begin{array}{l}4.06 \\
1.55\end{array}$}} & \multicolumn{3}{|c|}{6.46} & \multicolumn{3}{|c|}{2.53} \\
\hline & ts & & & & \multicolumn{3}{|c|}{7.27} & \multicolumn{3}{|c|}{2.95} \\
\hline & Sig. & & & & \multicolumn{3}{|c|}{$* *$} & \multicolumn{3}{|c|}{$* *$} \\
\hline
\end{tabular}


Table 25 The diminution index of the distal buccolingual diameter of the third molars of Macaca genus

\begin{tabular}{|c|c|c|c|c|c|c|c|}
\hline & & \multicolumn{3}{|c|}{ B } & \multicolumn{3}{|c|}{$\mathrm{C}$} \\
\hline & & $\mathrm{N}$ & $\bar{X}$ & S D & $\mathrm{N}$ & $\bar{X}$ & S D \\
\hline & $\underline{\mathrm{M}_{3}}$ & 30 & $16 \cdot 30$ & 4.43 & 27 & 13.22 & 4.80 \\
\hline & $\overline{\mathrm{M}_{3}}$ & 27 & 9.78 & 4.40 & 30 & 10.20 & 5.04 \\
\hline \multirow{3}{*}{$\underline{\mathrm{M}_{3}}-\overline{\mathrm{M}_{3}}$} & $\operatorname{diff}$. & & 6.52 & & & 3.02 & \\
\hline & ts & & 5.56 & & & 2.31 & \\
\hline & Sig. & & $* *$ & & & $*$ & \\
\hline
\end{tabular}

Test of significant difference on each measurement value among the three Macaca genus $\left(\mathrm{M}_{1}\right)$

\begin{tabular}{|c|c|c|c|c|c|c|c|c|c|c|}
\hline & & \multicolumn{3}{|c|}{$A-B$} & \multicolumn{3}{|c|}{$A-C$} & \multicolumn{3}{|c|}{$B-C$} \\
\hline & & diff. & ts & Sig. & diff. & ts & Sig. & diff & ts & Sig. \\
\hline \multirow{2}{*}{1} & $\mathrm{U}$ & -1.11 & 10.54 & $* *$ & -0.21 & 2.77 & $* *$ & 0.91 & 9.32 & $* *$ \\
\hline & $\mathrm{L}$ & -0.62 & 5.27 & $* *$ & -0.05 & 0.65 & & 0.57 & 4.57 & $* * *$ \\
\hline \multirow{2}{*}{2} & $\mathrm{U}$ & -0.80 & 8.34 & $* *$ & 0.19 & 2.48 & * & 0.99 & 9.40 & $* *$ \\
\hline & $\mathrm{L}$ & -0.59 & 6.94 & $* *$ & -0.21 & 2.68 & $* *$ & 0.38 & 3.51 & $* *$ \\
\hline \multirow{2}{*}{3} & $\mathrm{U}$ & -0.44 & 4.47 & $* *$ & 0.49 & 5.85 & $* *$ & 0.93 & 8.85 & $* *$ \\
\hline & L & -0.65 & 7.17 & $* *$ & -0.01 & 0.12 & & 0.64 & 6.07 & $* *$ \\
\hline \multirow{2}{*}{4} & $\mathrm{U}$ & -2.39 & 2.04 & * & -7.20 & 7.03 & $* *$ & -4.81 & 4.03 & $* *$ \\
\hline & $\mathrm{L}$ & 4.80 & 3.55 & $* *$ & 6.11 & 4.81 & $* *$ & 1.31 & 0.80 & \\
\hline \multirow{2}{*}{5} & $\mathrm{U}$ & -12.34 & 8.19 & $* *$ & -0.04 & 0.04 & & $12 \cdot 30$ & 8.39 & $* *$ \\
\hline & L & -7.86 & 6.19 & $* *$ & -2.47 & 2.76 & $* *$ & 5.39 & 3.79 & $* * *$ \\
\hline \multirow{2}{*}{6} & $\mathbf{U}$ & -0.29 & 7.04 & $* *$ & -0.26 & 7.09 & $* *$ & 0.03 & 0.72 & \\
\hline & $\mathrm{L}$ & 0.06 & 1.44 & & -0.20 & 5.51 & $* *$ & -0.26 & 5.81 & $* * *$ \\
\hline \multirow{2}{*}{7} & $\mathrm{U}$ & 3.63 & 6.25 & $* *$ & 4.20 & 7.69 & $* *$ & 0.57 & 0.95 & \\
\hline & $\mathrm{L}$ & -1.62 & 2.25 & $*$ & 3.00 & 5.10 & $* *$ & 4.62 & 6.59 & $* *$ \\
\hline \multirow{2}{*}{8} & $\mathrm{U}$ & -3.67 & 6.32 & $* *$ & $-4 \cdot 30$ & 7.65 & $* *$ & -0.63 & 1.01 & \\
\hline & $\mathrm{L}$ & 2.04 & 2.80 & $* *$ & -3.74 & 5.61 & $* *$ & -5.78 & 7.20 & $* *$ \\
\hline
\end{tabular}

1 : mesiodistal diameter

3 : distal buccolingual diameter

5 : occlusal surface area

6 : difference between mesial and distal buccolingual diameter

7 : mesiodistal index of buccolingual diameter

8 : diminution index of crown distal region
U : upper
L : lower
(Table 26 30) 
3 第 3 大巨歯

第 3 大曰歯は表 $22 に$ 示すごとく，上頢が下顎よりも小 さい数值を示し，その差は有意である。またニホンザル とカニクイザルとの間では, 上顎ではカニクイザルが大 きい数值を示し，下顎では差はない。

H 歯冠遠心側縮小示数

1 第 1 大田蒌

馬場 $(1978)^{9 \prime}$ がニホンザルについて，近心側と遠心 側の煩舌径との関係を縮小示数というもので示したのに 從って 3 種の比較を行ったのが表23である．上顎では力 ニクイザルが 7.47 で最も大きく，ついでニホンザルの 6.84で，アカゲザルが3.17で最も小さい.しかしカニク イザルとニホンザルの間に有意の差は認められず，アカ ゲザルは他の二者との間に著明な差を示しており，前二 者は近心側より遠心側に向って著しく縮小していること がうかがわれる．下顎では上顎に比べて縮小示数は小さ く，最も大きい数值のものがカニクイザルの4.84で，ア カゲザルの 1.10 ，ニホンザルのー0.94となっており，近 心側に対して遠心側の縮小はきわめて小さく，特に二ホ ンザルではむしろ反対に遠心側が近心側よりも大きい。

2 第 2 大曰图
同じく第 2 大日米についてみると表 24 のごとく，上下 顎とも第 1 大曰曾よりも大きい数值を示している．上顎 では三者間にはとんど差はなく，また下顎ではカニクイ ザルが最も大きい示数值を示し，以下アカゲザル，二ホ ンザルの䫍となっており，カニクイザルとニホンザルの 間にのみ有意の差がみられた。.上下筫の比較ではやはり 上顎が大きい縮小示数值を示していた。

\section{3 第 3 大臼歯}

第 3 大曰霜に拈ける縮小示数は表 25 亿示すごとく，第 1 および第 2 大罒霜に比べて，さらにその数值が大き く，近心側から遠心側への縮小が著しくなっているてと を示している．上䫈ではニホンザルがカニクイザルより も大きく，下顎ではカニクイザルがニホンザルよりも大 きい。ただし下顎では峏者間に差はない。また上顎は下 顎よりも大きい数值を示していた。

I 各種属間の差について

さて，てれまでの各計測項目や示数值について，マカ ク属 3 種の相互間の差の検定結果をまとめたものが表26 (第 1 大曰歯)，表27（第 2 大曰柬）および表28（第 3 大 臼荬) である.一般に電の大きさについては，ニホンザ ルと他の二者間では著明な差を示しているが，アカゲザ

Table 27

Test of significant difference of each measurements value among the three Macaca genus $\left(\mathrm{M}_{2}\right)$

\begin{tabular}{|c|c|c|c|c|c|c|c|c|c|c|}
\hline & & \multicolumn{3}{|c|}{$A-B$} & \multicolumn{3}{|c|}{$A-C$} & \multicolumn{3}{|c|}{$B-C$} \\
\hline & & $\operatorname{diff}$. & ts & Sig & diff. & ts & Sig. & diff & ts & Sig. \\
\hline \multirow{2}{*}{1} & $\mathrm{U}$ & -1.36 & 2.90 & $* *$ & -0.06 & 0.32 & & 1.30 & 8.68 & $* *$ \\
\hline & $\mathrm{L}$ & -1.23 & 3.90 & $* *$ & 0.19 & 1.30 & & 1.04 & 6.51 & $* *$ \\
\hline \multirow{2}{*}{2} & $\mathrm{U}$ & -1.54 & 4.18 & $* *$ & -0.18 & 0.63 & \multirow[b]{2}{*}{$* *$} & 1.36 & 8.97 & $* *$ \\
\hline & $\mathrm{L}$ & -1.04 & 4.95 & $* *$ & -0.63 & 3.92 & & 0.41 & 3.05 & $* *$ \\
\hline \multirow{2}{*}{3} & $\mathrm{U}$ & -1.38 & 4.56 & $* *$ & -0.15 & 0.47 & \multirow[b]{2}{*}{$* *$} & 1.23 & 8.22 & $* *$ \\
\hline & $\mathrm{L}$ & -1.26 & 5.73 & $* *$ & -0.53 & 3.07 & & 0.73 & 5.11 & $* *$ \\
\hline \multirow{2}{*}{4} & $\mathrm{U}$ & 3.31 & 1.24 & & 0.55 & 0.15 & \multirow[b]{2}{*}{$* *$} & -2.76 & 1.72 & \\
\hline & $\mathrm{L}$ & 2.91 & 1.32 & & 9.29 & 3.57 & & 6.36 & 3.35 & $* *$ \\
\hline \multirow{2}{*}{5} & $\mathrm{U}$ & -24.59 & 3.66 & $* *$ & -2.01 & 0.65 & \multirow{4}{*}{$*$} & 22.58 & 10.10 & $* *$ \\
\hline & $\mathrm{L}$ & -16.32 & 4.50 & $* *$ & -4.95 & 2.45 & & $11 \cdot 37$ & 5.67 & $* *$ \\
\hline \multirow{2}{*}{6} & $\mathrm{U}$ & -0.12 & 0.83 & & 0.02 & 0.13 & & 0.14 & 2.06 & $*$ \\
\hline & $\mathrm{L}$ & 0.13 & 1.32 & & -0.13 & 1.20 & & -0.26 & 3.54 & $* * *$ \\
\hline \multirow{2}{*}{7} & $\mathrm{U}$ & -0.48 & 0.30 & & -0.39 & 0.17 & & 0.09 & 0.10 & \\
\hline & $\mathrm{L}$ & -2.82 & 2.02 & $*$ & 1.05 & 0.69 & & 3.87 & 3.81 & $* *$ \\
\hline \multirow{2}{*}{8} & $\mathrm{U}$ & 0.45 & 0.29 & & 0.49 & 0.23 & & 0.04 & 0.04 & \\
\hline & $\mathrm{L}$ & 2.85 & 1.92 & & -1.04 & 0.67 & & -3.89 & 3.67 & $* *$ \\
\hline
\end{tabular}


Table 28 Test of significant difference of each measurements value between the two Macaca genus $\left(\mathrm{M}_{3}\right)$

\begin{tabular}{|c|c|c|c|c|}
\hline & & \multicolumn{3}{|c|}{$B-C$} \\
\hline & & diff. & ts & Sig. \\
\hline \multirow{2}{*}{1} & $\mathrm{U}$ & 1.54 & 6.67 & $* *$ \\
\hline & $\mathrm{L}$ & 2.14 & 7.47 & $* *$ \\
\hline \multirow{2}{*}{2} & $\mathrm{U}$ & 1.38 & 6.05 & $* *$ \\
\hline & $\mathrm{L}$ & 0.72 & 4.24 & $* *$ \\
\hline \multirow{2}{*}{3} & $\mathrm{U}$ & 0.97 & 4.46 & $* *$ \\
\hline & $\mathrm{L}$ & 0.71 & 4.32 & $* *$ \\
\hline \multirow{2}{*}{4} & $\mathrm{U}$ & 1.20 & 0.65 & \\
\hline & $\mathrm{L}$ & 16.54 & 6.52 & $* *$ \\
\hline \multirow{2}{*}{5} & $\mathrm{U}$ & 23.40 & 6.90 & $* *$ \\
\hline & $\mathrm{L}$ & 23.73 & 6.72 & $* *$ \\
\hline \multirow{2}{*}{6} & $\mathrm{U}$ & 0.44 & 3.77 & $* *$ \\
\hline & $\mathrm{L}$ & 0.02 & 0.20 & \\
\hline \multirow{2}{*}{7} & $\mathrm{U}$ & -2.56 & 2.01 & $*$ \\
\hline & $\mathrm{L}$ & 0.08 & 0.06 & \\
\hline \multirow{2}{*}{8} & $\mathrm{U}$ & 3.08 & 2.92 & $* *$ \\
\hline & $\mathrm{L}$ & -0.42 & 0.33 & \\
\hline
\end{tabular}

ルとカニクイザルとの聞ではそれほど大きな差はない.

\section{J 大四蒾各茵間の差について}

第 1 大臼蒾之第 2 大目柬間の差については表29に示す ごとく，いずれのマカク属にお゙いても，ほとんど第 2 大 日菌が大きい，第 1 大田柬が大きいのは歯冠示数と煩舌 经近遠心示数のみである. 第 2 大曰歯と第 3 大田歯間の 差については表30に示すごとく，第 1 と第 2 大臼雨間ほ どの差はなく，一般に上顩では第 2 大曰霜が大きいが， 下顎では第 3 大臼篓が大きいといえる.

\section{$\mathrm{K}$ 大曰菌示数}

歯冠近遠心径，歯冠近心煩舌径および咬合面面積につ いて，第 1 大囦歯を基準にして第 2 大曰曾拈よび第 3 大 曰雨の百分率を算出してみた．まず第 1 大曰曾に対する 第 2 大曰歯の示数值は表 $31 ， 32 ， 33$ 亿示す通りである.

近遠心径は各種属とも第 1 大曰歯より第 2 大曰歯が大 きいため示数值は 100 以上となっている .上顎では二ホ ンザルが最も大きく，下顎ではアカゲザルが最も大き い. 上頼に比べると下顎が大きい数值を示しているが， ニホンザルでは上下額間に有意の差はない。

近心煩舌径は上下顎ともニホンザルが最も大きい示数 值で，上下顎間においては各種属とも下䫟が大きい示数 值であった。

Table 29

Test of significant difference of each measurements value between the first and second molars $\left(M_{1}-M_{2}\right)$

\begin{tabular}{|c|c|c|c|c|c|c|c|c|c|c|}
\hline & & \multicolumn{3}{|c|}{ A } & \multicolumn{3}{|c|}{ B } & \multicolumn{3}{|c|}{$\mathrm{C}$} \\
\hline & & diff. & ts & Sig. & diff. & ts & Sig. & diff. & ts & Sig. \\
\hline \multirow{2}{*}{1} & $\mathrm{U}$ & -0.88 & 5.00 & $* *$ & -1.13 & 5.64 & $* *$ & -0.73 & 10.35 & $* *$ \\
\hline & $\mathrm{L}$ & -0.67 & 6.10 & $* *$ & -1.28 & $5 \cdot 42$ & $* *$ & -0.81 & 9.66 & $* *$ \\
\hline \multirow{2}{*}{2} & $\mathrm{U}$ & -0.55 & 4.58 & $* *$ & -1.29 & 7.52 & $* *$ & -0.92 & 9.57 & $* *$ \\
\hline & $\mathrm{L}$ & -0.66 & 7.16 & $* *$ & -1.11 & 7.20 & $* *$ & -1.08 & 11.73 & $* *$ \\
\hline \multirow[b]{2}{*}{3} & $\mathbf{U}$ & 0.05 & 0.30 & & -0.89 & 6.15 & $* *$ & -0.59 & 5.58 & $* *$ \\
\hline & $\mathrm{L}$ & -0.29 & 2.57 & $*$ & -0.90 & 5.75 & $* *$ & -0.81 & 8.49 & $* *$ \\
\hline \multirow{2}{*}{4} & $\mathrm{U}$ & -4.15 & 1.91 & & 1.37 & 0.97 & & 3.42 & 3.53 & $* *$ \\
\hline & $\mathrm{L}$ & $4 \cdot 12$ & 1.90 & & $2 \cdot 25$ & 1.23 & & 7.30 & 4.94 & $* *$ \\
\hline \multirow{2}{*}{5} & $\mathrm{U}$ & -9.25 & 4.90 & $* *$ & -21.50 & 7.27 & $* *$ & -11.22 & $10 \cdot 15$ & $* *$ \\
\hline & $\mathrm{L}$ & -9.77 & 9.74 & $* *$ & -18.25 & 6.84 & $* *$ & -12.47 & 11.28 & $* *$ \\
\hline \multirow[b]{2}{*}{6} & $\mathrm{U}$ & -0.55 & 5.93 & $* *$ & -0.39 & 6.49 & $* *$ & -0.28 & 6.02 & $* *$ \\
\hline & $\mathrm{L}$ & -0.34 & 5.21 & $* *$ & -0.27 & $4 \cdot 31$ & $* *$ & -0.27 & 5.47 & $* *$ \\
\hline \multirow{2}{*}{7} & $\mathrm{U}$ & 7.59 & 5.61 & $* *$ & 3.48 & 4.99 & $* *$ & 3.00 & 4.27 & $* *$ \\
\hline & $\mathbf{L}$ & 4.74 & 4.20 & $* *$ & 3.54 & 3.96 & $* *$ & 2.79 & 3.87 & $* *$ \\
\hline \multirow{2}{*}{8} & $\mathbf{U}$ & -7.60 & 5.64 & $* *$ & -3.48 & 5.21 & $* *$ & -2.81 & 4.09 & $* *$ \\
\hline & $\mathbf{L}$ & -5.61 & 4.92 & $* *$ & -4.80 & 5.07 & $* *$ & -2.91 & 3.72 & $* *$ \\
\hline
\end{tabular}


Table $30 \quad$ Test of significant difference of each measurements value between the second and third molars $\left(M_{2}-M_{3}\right)$

\begin{tabular}{|c|c|c|c|c|c|c|c|}
\hline & & \multicolumn{3}{|c|}{ B } & \multicolumn{3}{|c|}{$\mathrm{C}$} \\
\hline & & diff. & ts & Sig. & diff. & ts & Sig \\
\hline \multirow{2}{*}{1} & $\mathrm{U}$ & 0.06 & 0.22 & \multirow[b]{2}{*}{$* *$} & 0.30 & 3.03 & $* *$ \\
\hline & $\mathrm{L}$ & -2.34 & 7.04 & & -1.24 & 10.56 & $* *$ \\
\hline \multirow{2}{*}{2} & $\mathrm{U}$ & 0.25 & 1.08 & & 0.27 & 1.79 & \\
\hline & $\mathrm{L}$ & -0.25 & 1.25 & \multirow{3}{*}{$* *$} & 0.06 & 0.50 & \\
\hline \multirow{2}{*}{3} & $\mathrm{U}$ & 0.72 & 3.93 & & 0.46 & 2.84 & $* *$ \\
\hline & $\mathrm{L}$ & 0.22 & 1.11 & & 0.20 & 1.56 & \\
\hline \multirow{2}{*}{4} & $\mathrm{U}$ & -3.72 & 2.74 & $* *$ & 0.24 & 0.12 & \\
\hline & $\mathrm{L}$ & -29.01 & 15.38 & $* *$ & -18.83 & 8.50 & $* *$ \\
\hline \multirow{2}{*}{5} & $\mathrm{U}$ & 2.51 & 0.62 & & 3.33 & 2.11 & $*$ \\
\hline & $\mathrm{L}$ & -19.95 & 6.12 & $* *$ & -7.59 & 4.96 & $* *$ \\
\hline \multirow{2}{*}{6} & $\mathrm{U}$ & -0.46 & 4.70 & $* *$ & -0.16 & 1.92 & \\
\hline & $\mathrm{L}$ & -0.42 & 4.90 & $* *$ & -0.14 & 1.74 & \\
\hline \multirow{2}{*}{7} & $\mathrm{U}$ & 5.38 & 5.63 & $* *$ & 2.73 & 2.32 & $*$ \\
\hline & $\mathrm{L}$ & 5.77 & 4.97 & $* *$ & 1.98 & 1.79 & \\
\hline \multirow{2}{*}{8} & U & -5.98 & 6.54 & $* *$ & -2.94 & 2.63 & $* *$ \\
\hline & $\mathrm{L}$ & -5.92 & 5.20 & $* *$ & -2.45 & 2.15 & $*$ \\
\hline
\end{tabular}

Table 31 The molar index of the mesiodistal diameter of Macaca genus $\left(\mathrm{M}_{2} / \mathrm{M}_{1}\right)$

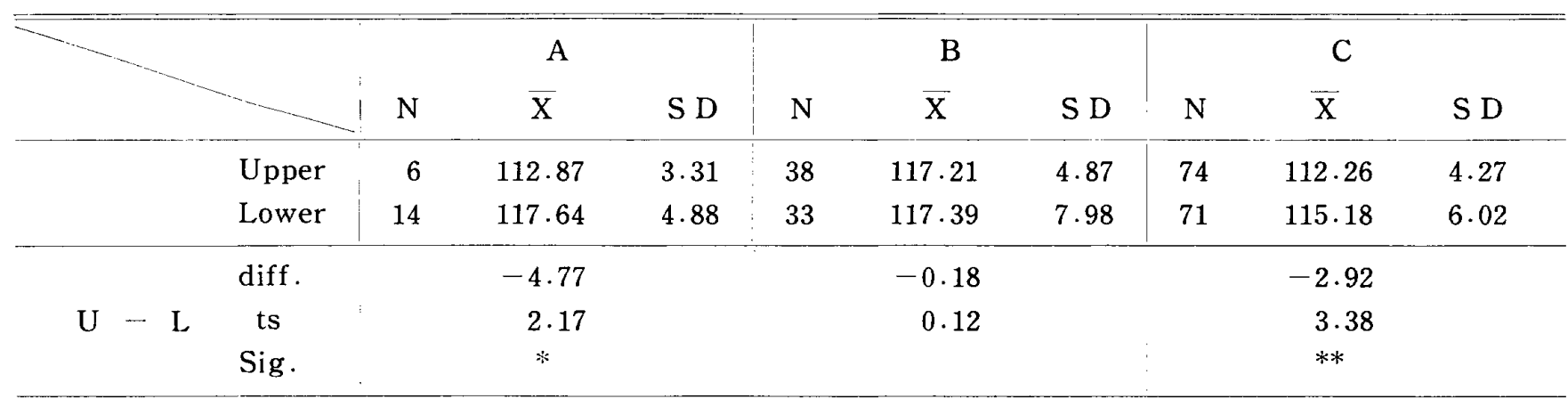
The molar index of the buccolingual diameter of Macaca genus $\left(\mathrm{M}_{2} / \mathrm{M}_{1}\right)$

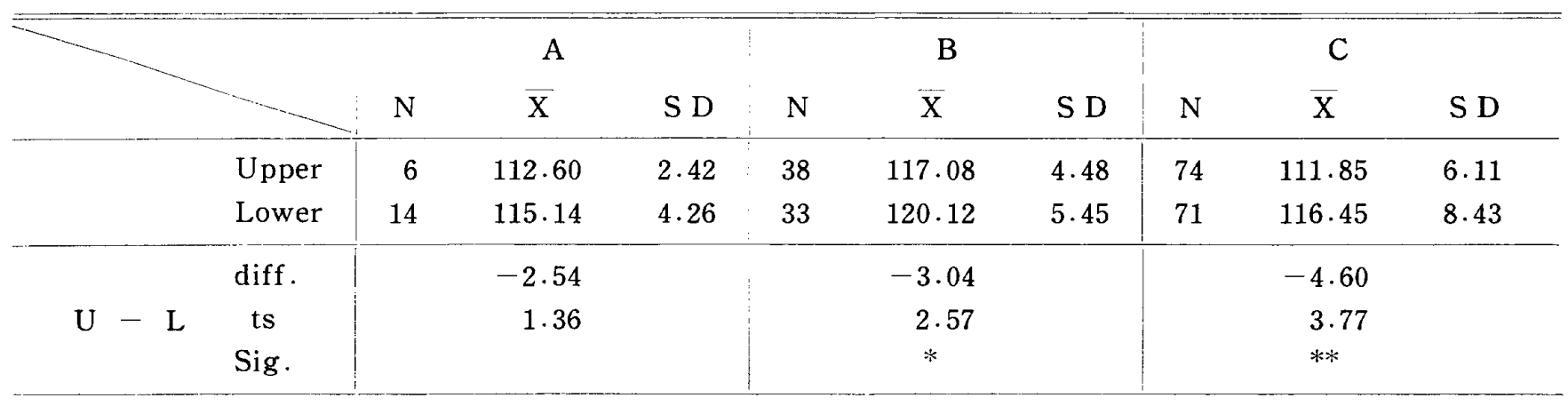


Table 33

The molar index of the occlusal surface area of Macaca genus $\left(\mathrm{M}_{2} / \mathrm{M}_{1}\right)$

\begin{tabular}{|c|c|c|c|c|c|c|c|c|c|c|}
\hline & & \multicolumn{3}{|c|}{$\mathrm{A}$} & \multicolumn{3}{|c|}{ B } & \multicolumn{3}{|c|}{$\mathrm{C}$} \\
\hline & & $\mathrm{N}$ & $\bar{X}$ & S D & $\mathrm{N}$ & $\bar{X}$ & S D & $\mathrm{N}$ & $\overline{\mathrm{X}}$ & S D \\
\hline & Upper & 6 & 127.17 & 6.44 & 38 & 137.47 & 9.14 & 74 & 125.50 & 8.37 \\
\hline & Lower & 14 & 131.93 & 3.30 & 33 & 142.54 & 10.71 & 71 & 135.18 & 14.41 \\
\hline \multirow{3}{*}{$\mathrm{U}-\mathrm{L}$} & $\operatorname{diff}$ & \multicolumn{3}{|c|}{-4.76} & \multicolumn{3}{|c|}{-5.07} & \multicolumn{3}{|c|}{-9.68} \\
\hline & ts & \multicolumn{3}{|c|}{2.21} & \multicolumn{3}{|c|}{2.15} & \multicolumn{3}{|c|}{4.97} \\
\hline & Sig. & \multicolumn{3}{|c|}{$*$} & \multicolumn{3}{|c|}{$*$} & \multicolumn{3}{|c|}{$* *$} \\
\hline
\end{tabular}

Table 34 The molar index of the mesiodistal diameter of Macaca

genus

\begin{tabular}{|c|c|c|c|c|c|c|c|}
\hline & & \multicolumn{3}{|c|}{ B } & \multicolumn{3}{|c|}{$\mathrm{C}$} \\
\hline & & $\mathrm{N}$ & $\bar{X}$ & S D & $\mathrm{N}$ & $\bar{X}$ & S D \\
\hline & Upper & 30 & 119.17 & 6.65 & 27 & 109.48 & 6.62 \\
\hline & Lower & 27 & 152.82 & 9.66 & 29 & 137.14 & 15.00 \\
\hline \multirow{3}{*}{$\mathrm{U}-\mathrm{L}$} & diff. & \multicolumn{3}{|c|}{-33.65} & \multicolumn{3}{|c|}{-27.66} \\
\hline & ts & \multicolumn{3}{|c|}{15.45} & \multicolumn{3}{|c|}{8.81} \\
\hline & Sig. & \multicolumn{3}{|c|}{$* *$} & \multicolumn{3}{|c|}{$* *$} \\
\hline
\end{tabular}

Table 35 The molar index of the buccolingual diameter of Macaca

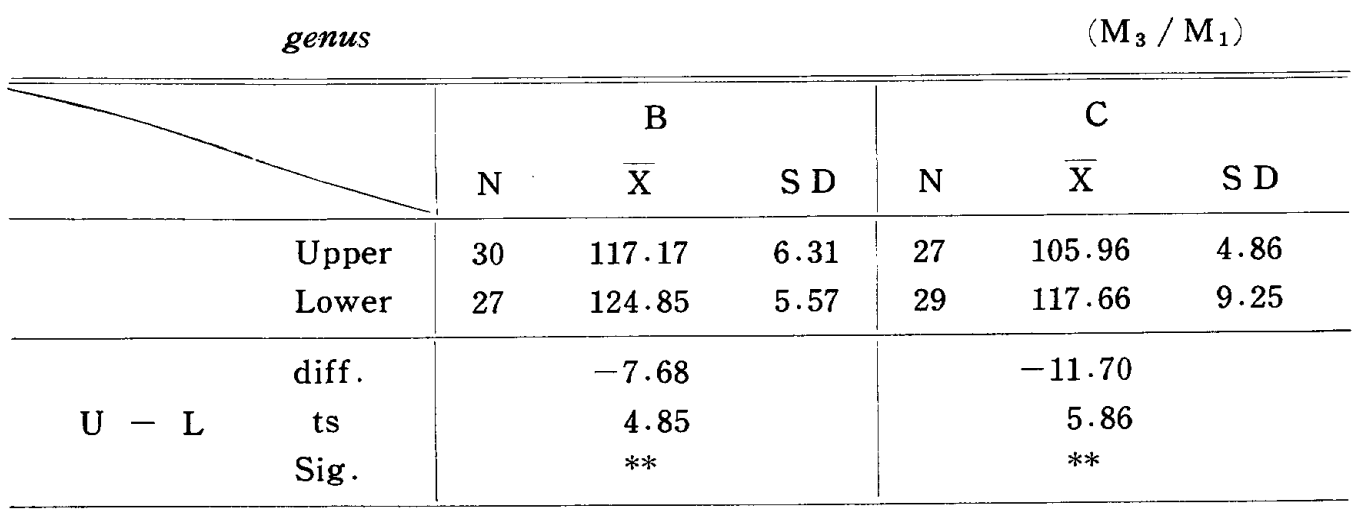

Table 36 The molar index of the occlusal surface of Macaca genus

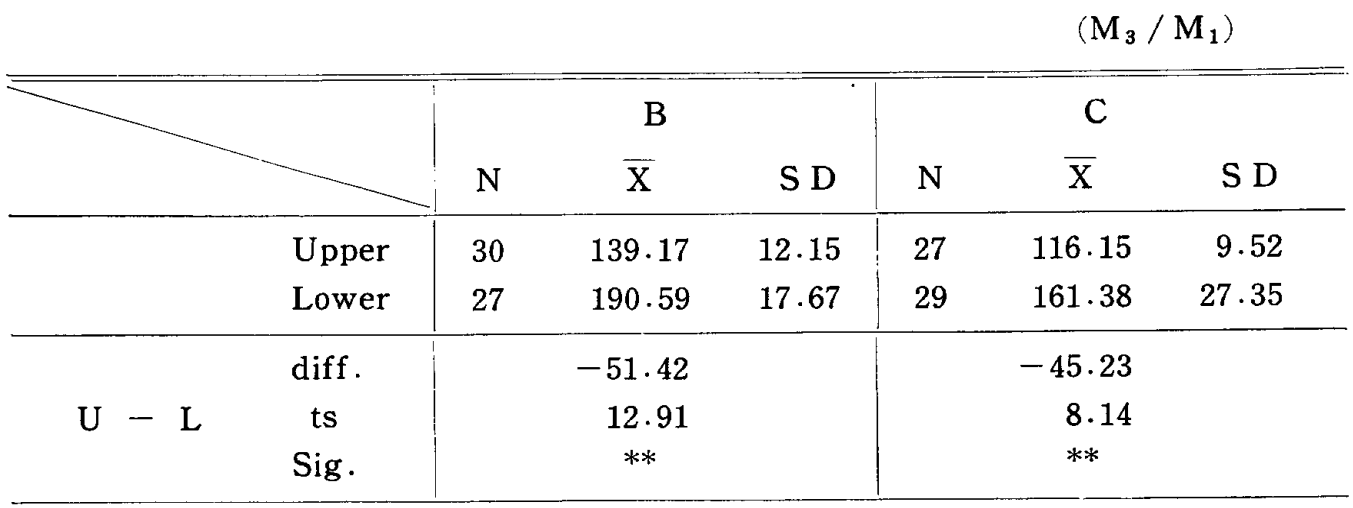


Table $37 \quad$ Test of significant difference of molar index value among the three Macaca genus

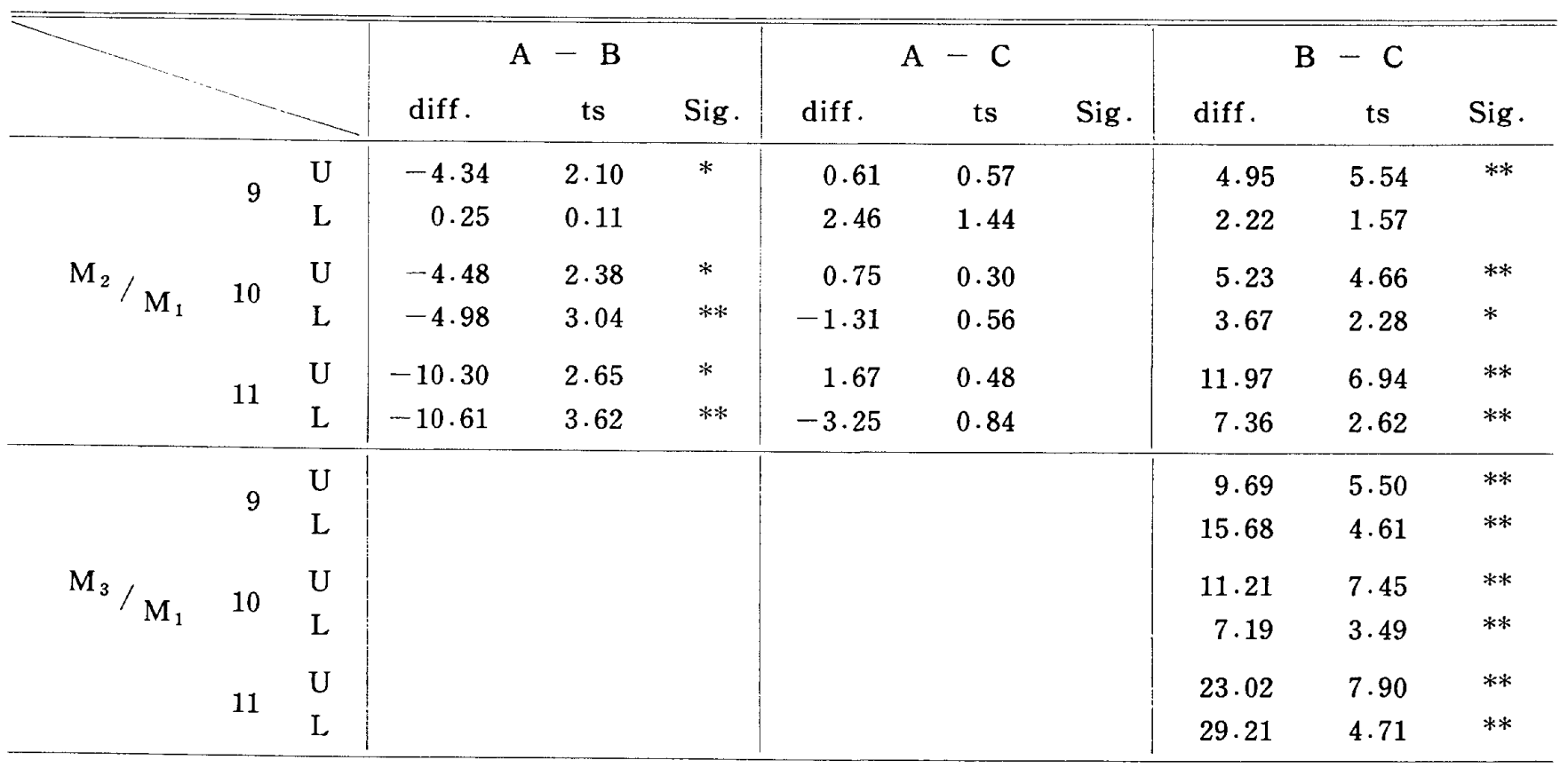

$9:$ Molar index of the mesiodistal diameter

10 : Molar index of the buccolingual diameter

11: Molar index of the occlusal surface area

咬合面面積においては，やはり上下䫟とも二ホンザル が最も大きい示数值を示し，上下䫟間の比較では上顎よ り下顎の方が大きい示数值を示していた。

第 1 大臼曾に対する第 3 大曰歯の示数值は表 34,35 , 36亿示す通りである，近遠心径, 近心煩舌径, 咬合面面 積ともに二ホンザルがカニクイザルよりも大きい数值を 示しており，また.上下咢間ではいずれも下顎が上顎より も著明に大きい数值を示していた。

以上の大曰菌示数において，3 種属間の差の検定を行

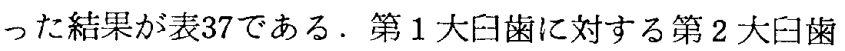
の示数值では，二ホンザルが他の 2 種よりも著しく大き い数值を示して，その差が有意であるが，カニクイザル とアカゲザルとの間では有意の差はない．また第 1 大臼 柬に対する第 3 大四䨑の示数值でも二ホンザルがカニク イザルに対して有意の差を示して大きい.

\section{考察ならびに総括}

マカク属（macaca）は霊長類のなかでは狭舅猿(catarrhini) のオナガザル科 (cercopithecoidea) に属し， アジア地域に㕕く分布し，適応性の盛んなととはおそら くサル類中で最もすぐれているといわれている12)。 カク属の霜式は他の狭鼻猿類やヒ卜科と全く同じであ
る、公鼻猿類では $\mathrm{I} \frac{2}{2} \mathrm{C} \frac{1}{1} \mathrm{P} \frac{3}{3} \mathrm{M} \frac{3}{3}=36$ であるととか ら，小曰歯が 1 本消失していることになる，茂原（1977） 14) 亿よると大臼菌の形態は食性をもっともよく反映し， 形態的パターンが複雑でありながら，種でとによく安定 していると述へている．また Clark（1960）15) は上下顝 大曰歯とも基本的には 4 咬頭 (下頻第 3 大曰雨は 5 咬頭) であるが，近，遠心のそれぞれの咬頭が横隆線によって 連絡する，いわゆる bilophodont type をなしており， すべての旧世界ザルに見られる特殊形態であるとしてい

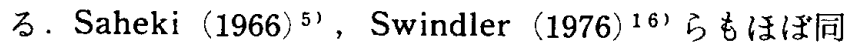
様な大臼歯形態を記載しており，下顥大曰雬においては 第 3 大曰菊のみに hypoconulid の発育が見られるとし ている，広鼻猿類については瀬戸口（1983）17がホエザ ルの上顩臼茵における原始形質について言及し，また名 取 $(1983)^{\left.1{ }^{18}\right)}$ はリスザルの上額臼菌の個体変異を 5 つの タイプに分類して，その見解をのべている。てのような マカク属の大四歯形熊を七トと比較した場合，歯式は一 致するものの咬合面形態には明らかな違いがみられ，ま た下箱大臼菊の hypoconulid の発育についてもとトで は第 1 大曰宷で最も良く，第 3 大曰柬においてはあまり 良くないといったととなど，相異点が認められる．著者 は狭鼻猿類のなかで最も分布地域の広いマカク属 3 種に 
ついて,その大臼蒾の計測を行い,同じマカク属において の比較を試み，形態学的な面から種々検討を行った．以 下，総括的に考察を加えながら述べてみるととにする．

1 歯の大きさについて

歯の大きさについて，他の霊長類と比較しながら，ま た今回調査した 3 種のマカク属間の関係を検討してみ

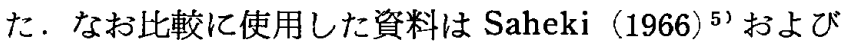
馬場（1979）10) の二ホンザル，中川（1971（6) のカニク イザル，藤田 (1967) ${ }^{19)}$ のヒトならびに Swindler（19 76) ${ }^{163}$ の各種の Primates よりのものである.上顎第 1 大曰歯の近迋心径は，図1に見られるごとく 3 種間では ニホンザルが他の 2 璉よりも著しく大きい，このことは 他の調查者の結果でもほぼ同様のととがいえる、狭鼻猿 類の中ではこれら 3 種はほぼ平均的の大きさを示してい るが，広鼻猿類に比べると大きく，また類人猿やヒトに 比べると小さい，近心煩舌径，遠心煩舌径についても近 遠心径とほぼ同様のことがいえる，ただし，アカゲザル とカニクイザルとの間では，近遠心径はカニクイザルが 大きいが，煩舌径ではアカゲザルが大きいといった関係 がみられた。したがって咬合面面積はニホンザルが他の

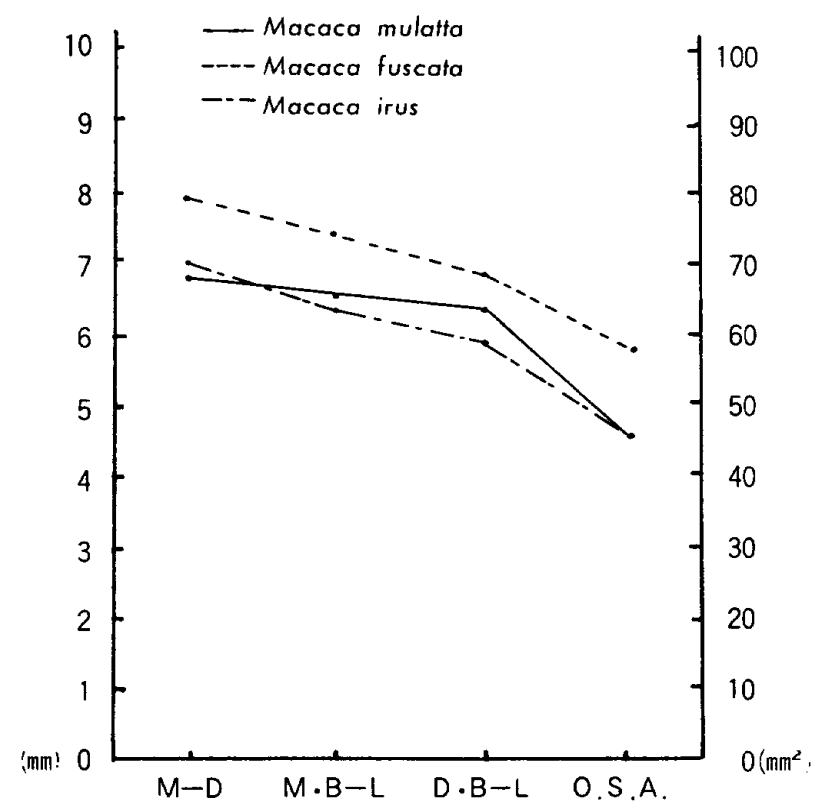

Fig. 1 Comparative diagram of the crown size on the upper first molar of Macaca genus.

M-D : Mesiodistal diameter (mm)

$\mathrm{M} \cdot \mathrm{B}-\mathrm{L}$ : Mesial buccolingual diameter $(\mathrm{mm}$ )

D.B-L : Distal buccolingual diameter ( $\mathrm{mm}$ )

O.S.A : Occlusal surface area $\left(\mathrm{mm}^{2}\right)$

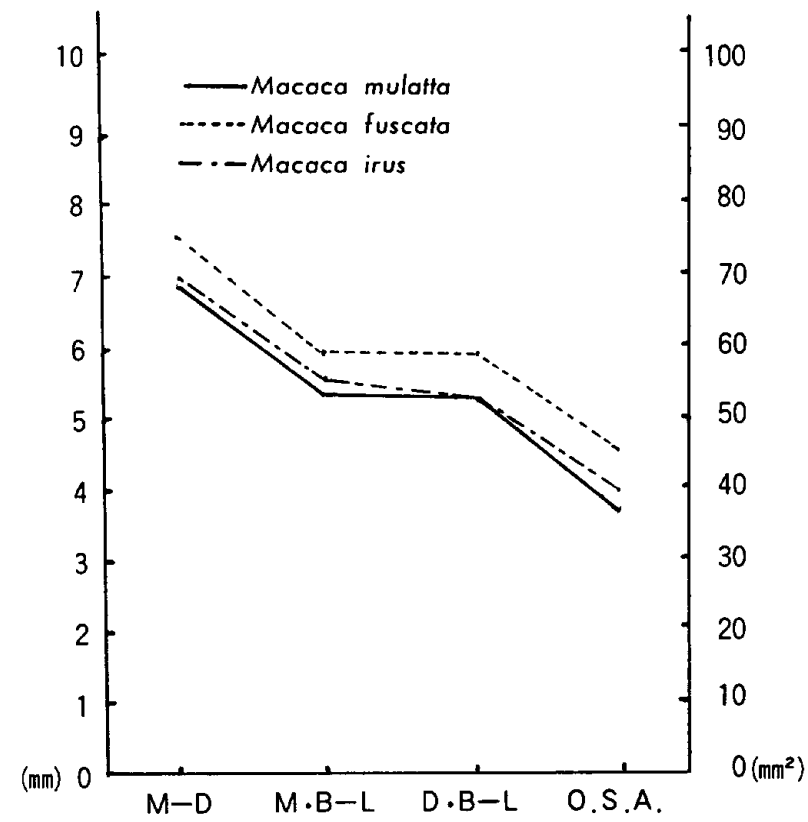

Fig. 2 Comparative diagram of the crown size on the lower first molar of Macaca genus.

二種に比べて著しく大で，カニクイザルとアカゲザルで はほとんど差を䜑めない。

下䝷第 1 大臼菊では近遠心径, 煩舌径, 咬合面面積と もに，図 2 に示すごとく，ニホンザルが最も大きく，ア カゲザルとカニクイザルはほとんど差はないものの，僅 かに後者が大きい。ニホンザルはブタオザルとほぼ同じ ぐらいであり，マカク属のなかでは大きい方である，し かし，ヒトやチンパンジーに比べると小さい. 煩舌径に ついても近遠心径の場合とほぼ同様の傾向を示してい る。

第 2 大曰霜における 3 種のマカク属の計測值を比較し たグラフは図 3 (上顎)，図 4 (下顎) である。上下顎 とも第 1 大日歯よりも大きく，乙れは特に狭鼻猿類で著 しい. 広鼻猿類ではホエザルを別にして，その他はほと んど第 2 大目雨が小さくなっている，類人猿でもそれ程 大きな差はなく，ヒトではむしろ第 1 よりも第 2 大臼歯 が小さくなっている。ママカ属は他の狭鼻猿類に比べる とほぼ平均的な大きさで，七ヒが最も大きいようであ る. 今回の調査結果では二ホンザルが他の 2 種よりも著 明に大きく，七七に次いで大きい。

マカク属の第 3 大曰雪は第 2 大曰雬に比べ，上顎では やや小さくなり，下顎では大きくなっている， 3 種の比 較グラフは図 5 (上䫛) と図 6 (下顎) である。狭鼻猿 類の中ではキイロヒヒが上顎でも第 3 大日歯が第 2 大巨 


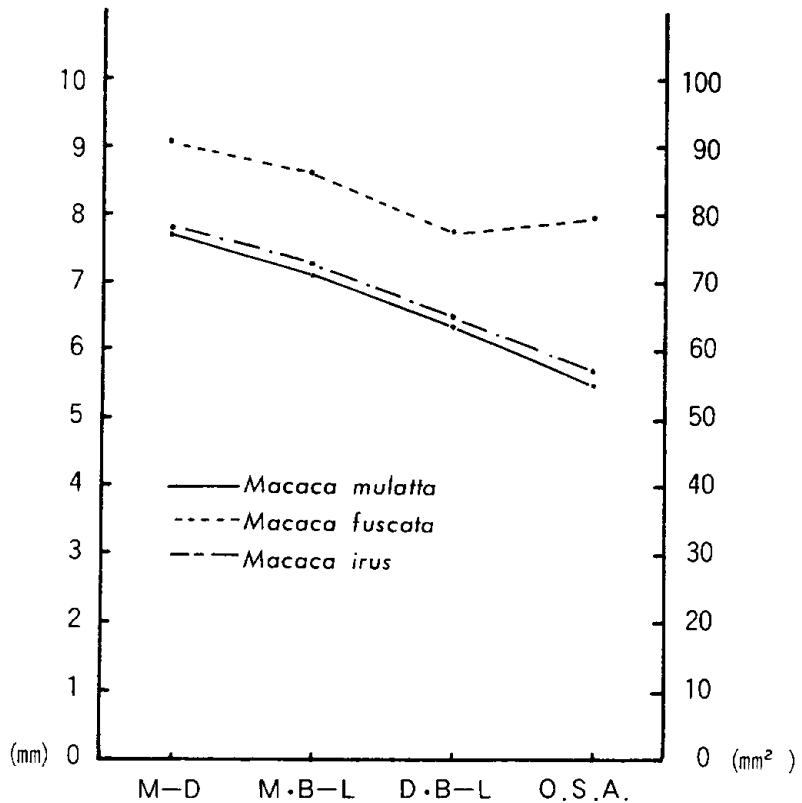

Fig. 3 Comparative diagram of the crown size on the second molar of Macaca genus.

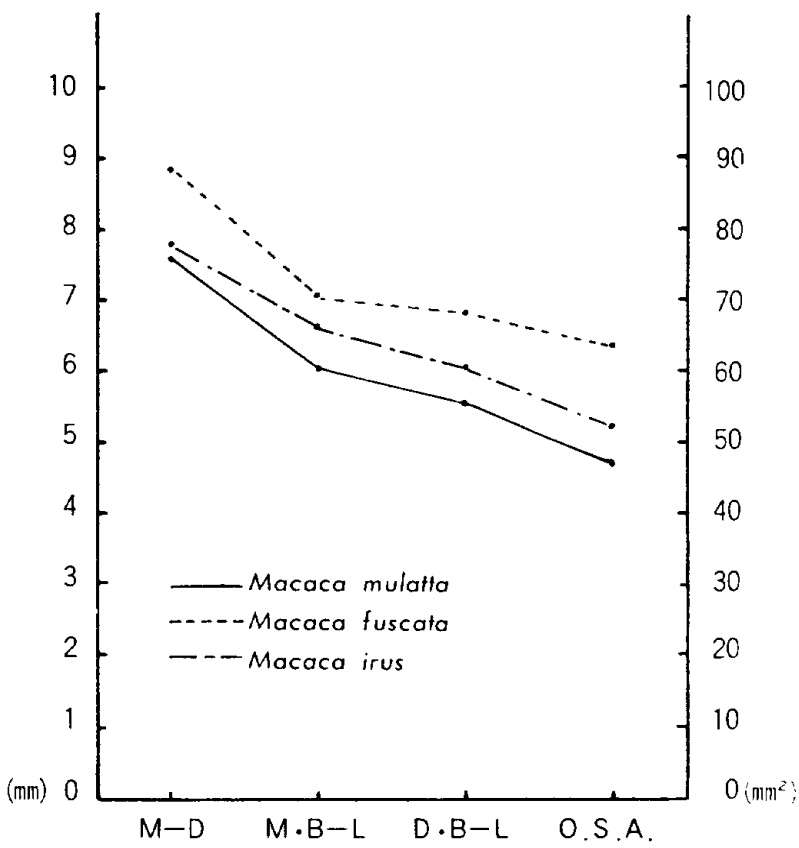

Fig. 4 Comparative diagrm of the crown size of the lower second molar of Macaca genus.

菌よりも大きいが，その他では小さくなっているか，あ るいは同じ程度である．乙の点広鼻猿類も一般に第 3 大 日柬が小さくなっており，また類人猿やヒトでも第 3 大 田蒾は特に小さくなっている．第 3 大曰雬においても二

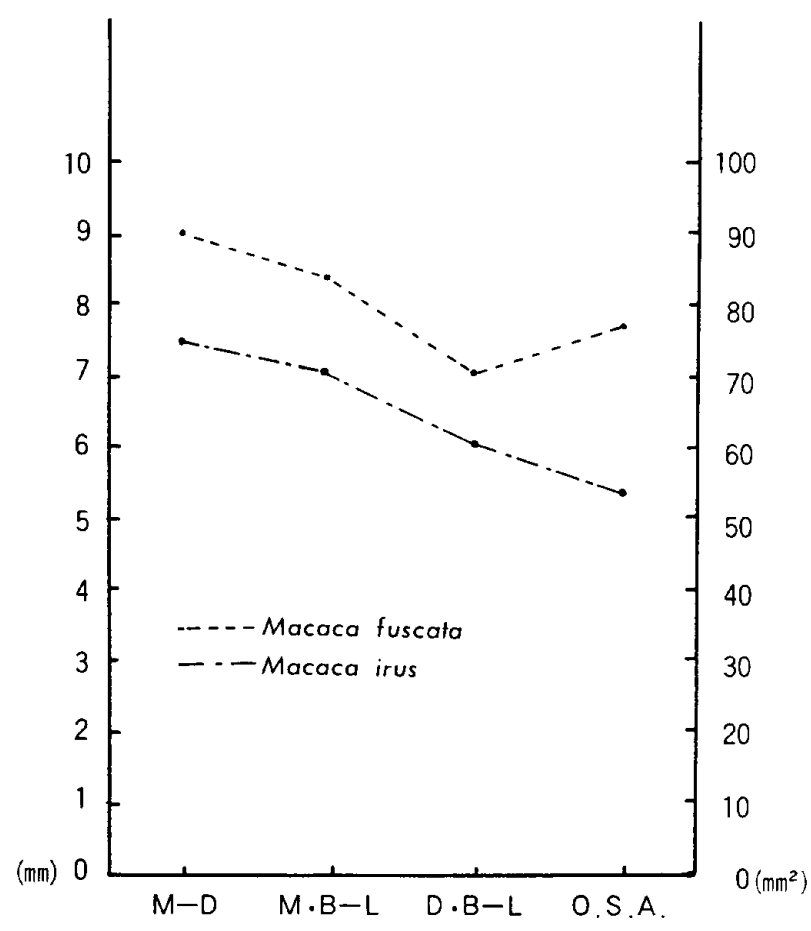

Fig. 5 Comparative diagram of the crown size on the upper third molar of Macaca genus.

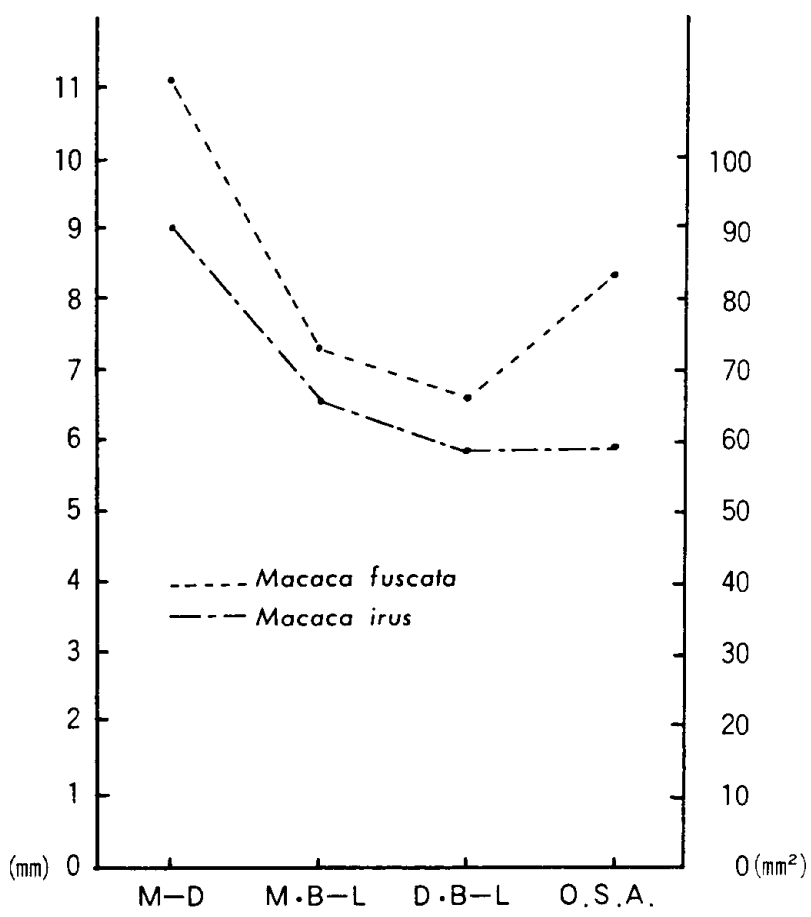

Fig. 6 Comparative diagram of the crown size on the lower third molar of Macaca genus.

ホンザルはカニタイザルよりも著しく大きく, 狭鼻猿類 の中では大きい方の部類に属する。 


\section{2 歯冠示数について}

歯冠の煩舌径に対する近遠心径の比率を示す示数值で ある。一般に霊長類では上顎よりも下顎の方が大きい示 数值を示すが，このことは下顎大曰歯では煩舌径に対し て近遠心径が相対的に大きいことを示している，七トの 下顎乳臼雪では近遠心径比へて煩舌径が極めて小さい が，乙れは乳目歯の原始性の一表徴と考えられる. 図 7 および図 8 は各種霊長類における上下顎の第 1 大臼歯の 菌冠示数をグラフで比較したものである，上顎について は，広鼻猿類と類人猿およびヒトでは示数值は大部分が 100 以下で, 煩舌径が近遠心径よりも大きい。しかし， 狭鼻猿類では示数值は 100 をこえ，近遠心径が煩舌径よ りもやや優っている。すなわち広鼻猿類では近遠心径が 極めて小さいが，狭鼻猿類になると，hypocone の発育 などによって, 煩舌径よりも近遠心径の成長発育が大き いため，示数值が大きくなったものと考えられる．そし て類人猿やヒトでは顎骨の発育段階之関連して, 近遠心 径の発育が相対的に小さくなり，再び示数值が小さくな
っていくるのと考えられる.

下顎第 1 大曰歯についてみると，ほとんどすべての霊 長類が 100 をてす示数值で, 近遠心径が, 煩舌径に比べ て大きいてとが認められる．狭鼻猿類はほぼ同じような 数值で, 特にマカク属は120〜130程度の数值である. 類 人猿になると，やや小さい数值となり，ヒトでは約 105.5 で，近遠心径と煩舌径にそれほど大きな差は認められな くなってくる，乙れは下顎骨の形態变化に対応して，歯 も形態の変化が生じ, 近遠心径は縮小儿, 煩舌径はやや 増大した結果と考えられる。

次に，歯冠示数は第 2 大曰菌抢よび第 3 大曰歯ではぼ のようになっているだろうか. 上顎では第 1 大曰歯に比 べて，各種霊長類ともにそれ程大きな差異はないようで ある、チンパンジーとヒトでは第 1 大四歯においてそれ ぞれ91.3，89.8と，いずれもマカク属に比べて小さい数 值であったが，第 2 ，第 3 大曰䁖になると次第に小さい 示数値を示してくるようになる.下顎においては各種霊 長類とも第 2 大曰歯は第 1 大田菌と大差はないが，狭鼻

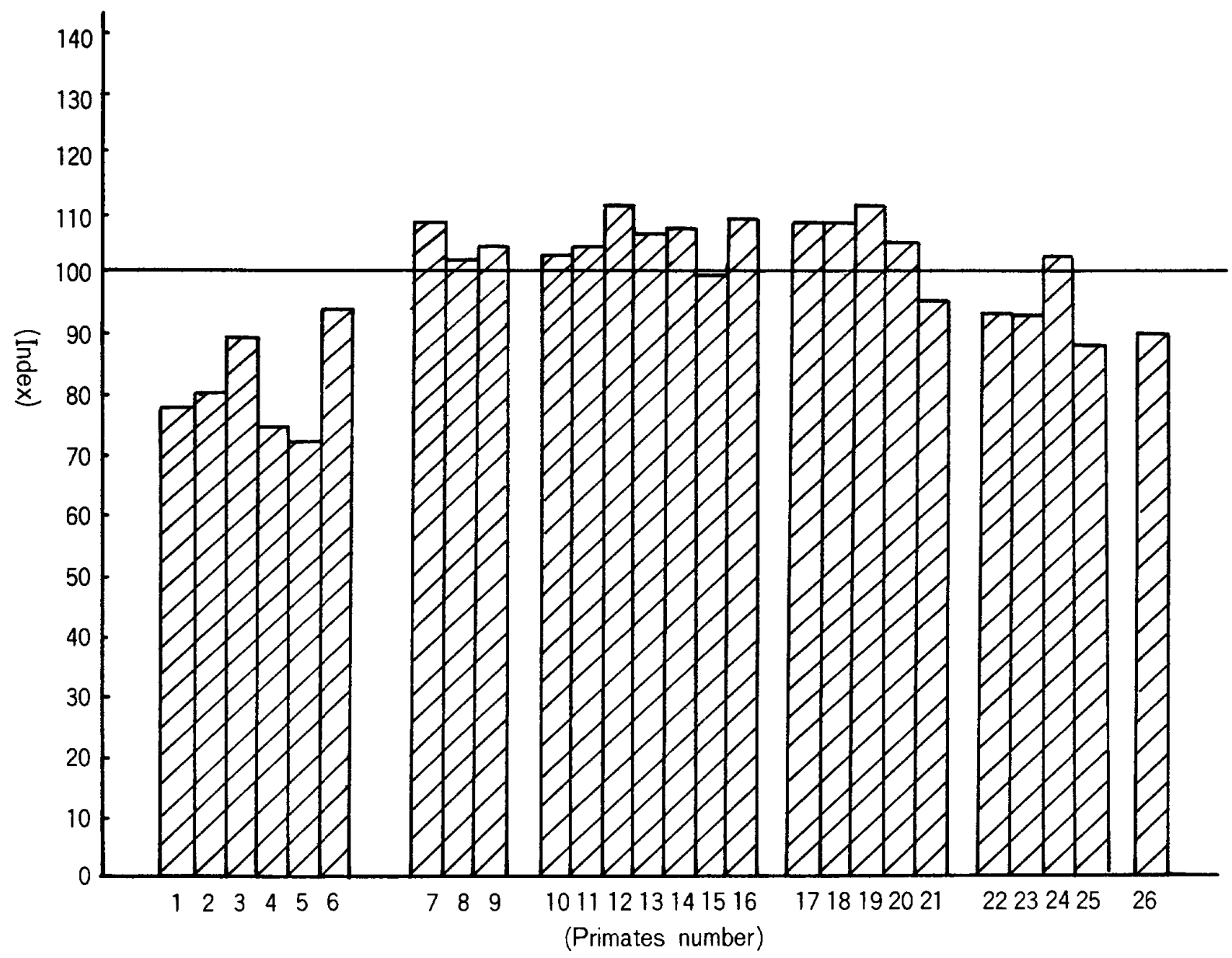

Fig. 7 Comparative graph of the crown index on the upper first molar of the primates. 


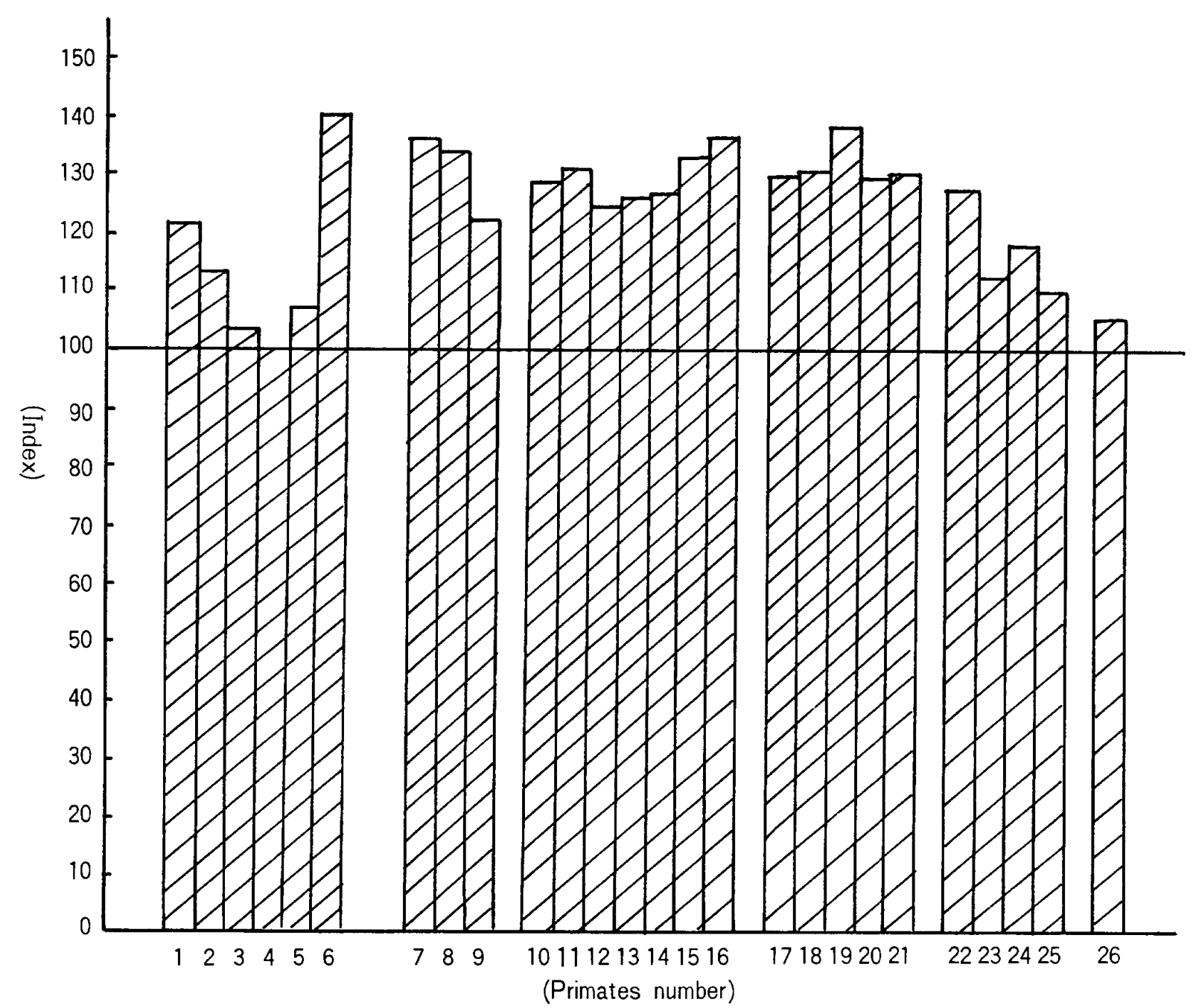

Fig. 8 Comparative graph of the crown index on the lower first molar of the primates.

猿類の第 3 大曰菌においては著明に大きな示数值を示し ている．すなわち狭鼻猿類の第 3 大臼㐘は煩舌径に対し て近遠心径がきわめて大きいととを示している。しかし 類人猿やヒトでは屰汇第 3 大曰歯が最も小さい数值を示 し，特にヒトでは第 3 大曰歯がかなり退化を示してお り, 煩舌径よりも近遠心径㴼小現象が強く認められる ことを示唆している，一方㹨鼻猿類においては，第 3 大 曰歯は未だ退化の段階にはなく, hy poconulid が分化し た状態であることを示している。

次にてれら三種のマカク属の第 1 大曰茵の計測值を他 の霊長類と比較したのが図 9 および図10である。これら の比較資料は主として Swindler (1976) ${ }^{161}$ および佐伯 ら (1961）2’より引用したものである。なおてれらの資 料はすべて今のものを用いた。したがって比較としては いささか難点もあると思われるが，一応その全容は判断 できるものと考えられる．てのグラフは縦軸に近遠心
径, 横軸に煩舌径をとったもので, 図 9 の上顎において は，Aの範囲は㳎鼻猿類の含まれる部分でホエザルだけ はBの範囲に入っている.一般に小さくて煩舌径が近遠 心径よりも大きい傾向にある、Bは獏鼻猿類のグループ である，広鼻猿類よりも大きくなり，近遠心径と煩舌径 との関係ではほぼ同じか, 近遠心径がやや大きいものが ある、Cはヒト科のグループで, テナガザルのみは Bグ ルーブに入っている．Bグルーブよりも更に大きくな り，煩舌径は近遠心径よりも大きくなっている。

下顎は図10のごとくで，その傾向は上顎とほぼ同様

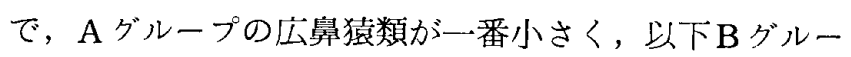
プの狭鼻猿類, Cグループのヒト科の順に大きくなって いる、また広鼻猿類のホエザルとヒ卜科のテナガザル は，上頻と同じく Bグループの中に含まれている。但し 上簤と異なり下顎では煩舌径に刘し近遠心徍が大きくな り，特に狭鼻猿類で最も著明である。 


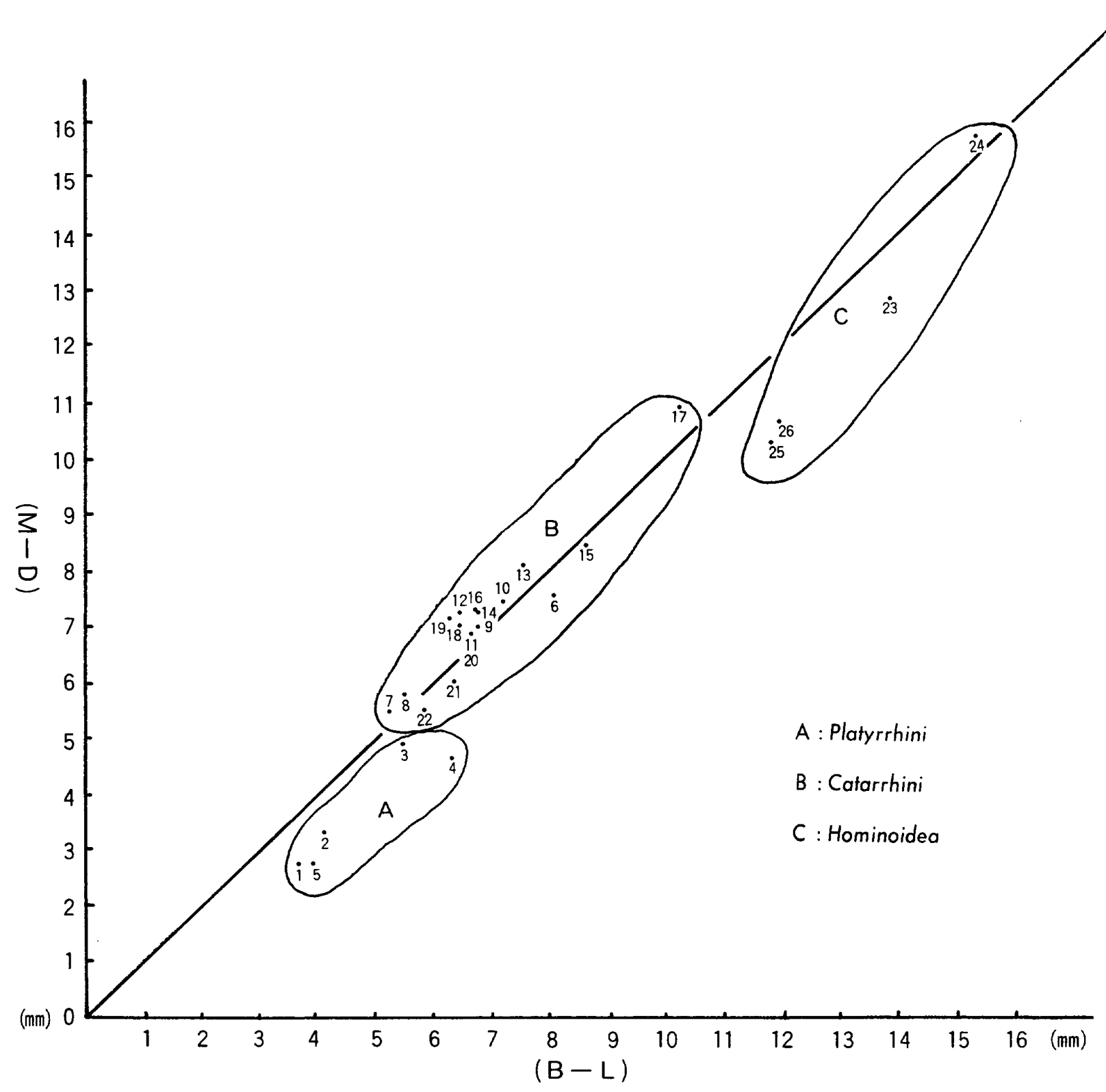

Fig. 9 Correlation diagram of the measurements value on the upper first molar of primates. 


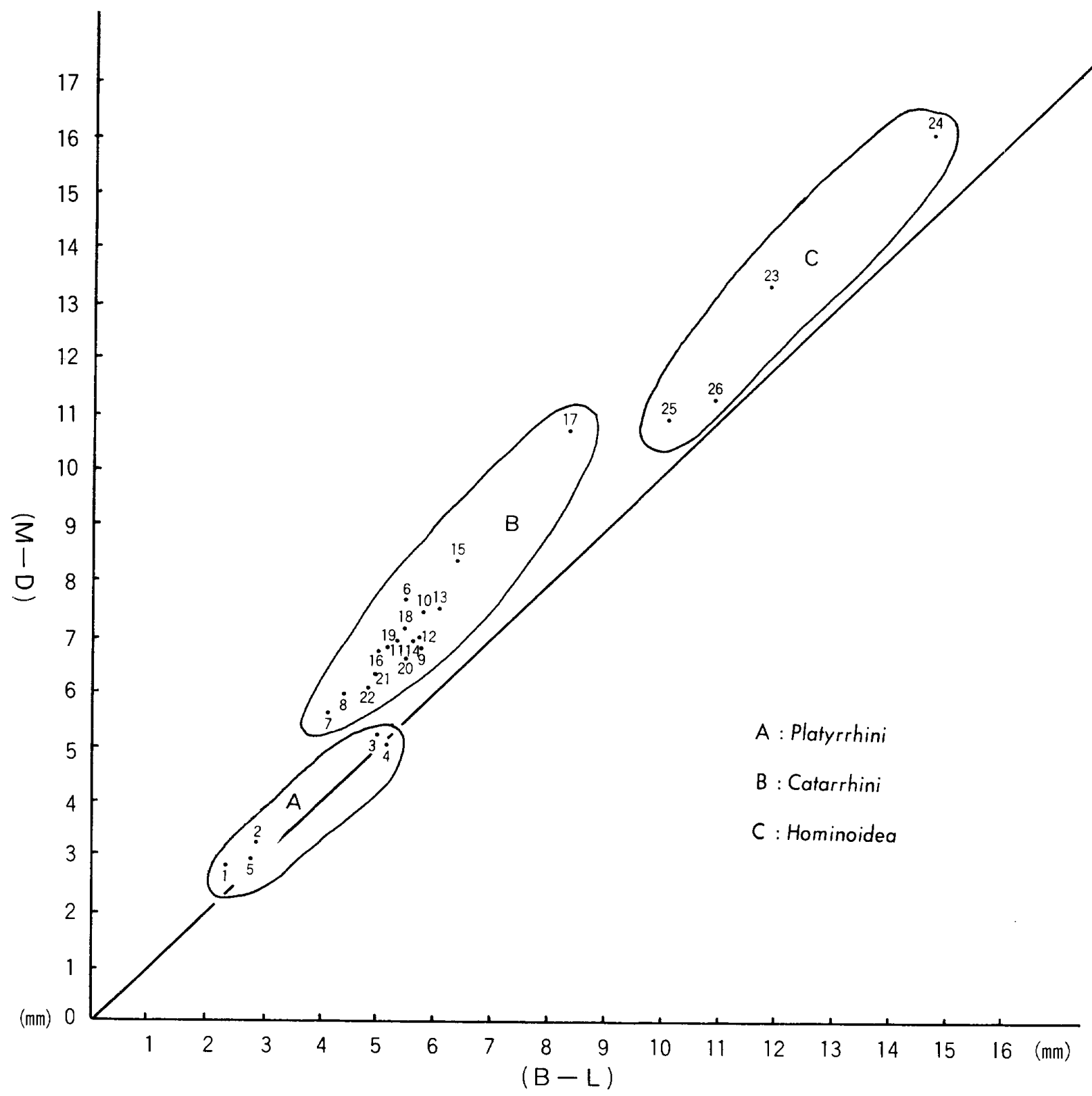

Fig. 10 Correlation diagram of the measurements value on the lower first molar of primates. 
Explanation of primates number 1-26 on the Fig. $7-10$

$\begin{aligned} 1 & \text { Tamarin } \\ 2 & \text { Aotus trivirgatus } \\ 3 & \text { Ateles geoffroyi } \\ 4 & \text { Cebus apella } \\ 5 & \text { Saimiri oerstedii } \\ 6 & \text { Alouatta seniculus } \\ 7 & \text { Cercopithecus cephus } \\ 8 & \text { Cercopithecus aethiops } \\ 9 & \text { Cercocebus albigena } \\ 10 & \text { Macaca nemestrina } \\ 11 & \text { Macaca mulatta } \\ 12 & \text { Macaca irus } \\ 13 & \text { Macaca fuscata } \\ 14 & \text { Macaca cyclopis } \\ 15 & \text { Macaca speciosa } \\ 16 & \text { Cynopithecus niger } \\ 17 & \text { Papio cynocephalus } \\ 18 & \text { Colobus polykomos } \\ 19 & \text { Nasalis larvatus } \\ 20 & \text { Pygathrix nemaeus } \\ 21 & \text { Presbytis phayrei } \\ 22 & \text { Hylobates klossii } \\ 23 & \text { Pongo pygmaeus } \\ 24 & \text { Gorilla gorilla } \\ 25 & \text { Pan troglodytes } \\ 26 & \text { Homo sapiens } \\ & \end{aligned}$

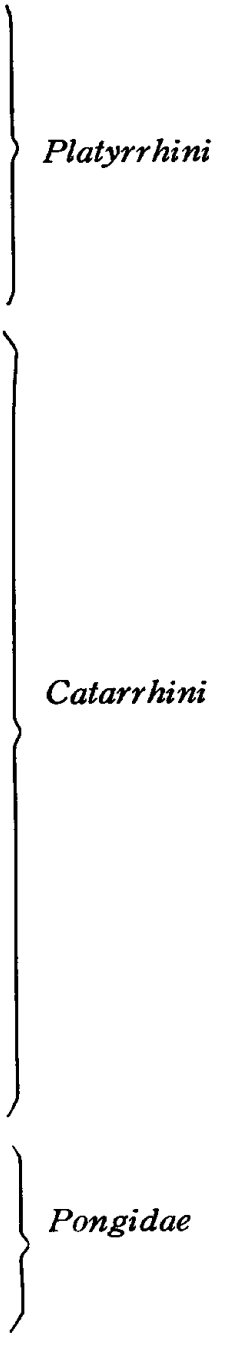

Hominidae
3 歯冠遠心側縮小示数について

菌冠の煩舌径について，近心側と遠心側の両者を計測 し，それら間の差異について検討してみた。一般に近心 煩舌径が遠心煩舌径よりも優っているが，まず単純に両 者閒の差をみてみると，上篔第 1 大四歯ではカニクイザ ル，ニホンザルが $0.5 \mathrm{~mm}$, アカゲザルが $0.2 \mathrm{~mm}$ で, これは広畀猿類よりも差は大きく，オランウータンやチ ンパンジーよりも差は小さい. 下顝第 1 大曰歯では広鼻 猿類，㹨鼻猿類，類人猿すべてにおいて上顎ほどの大き な差はなく，むしろ，遠心煩舌径が大きいものがかなり 見られる、第 2 大曰菌扔よび第 3 大四畨になると，上下 買とも第 1 大田茵よりも両者閒の差は大きくなり，特に 第 3 大曰雪において著しい.

近心煩舌径に対する遠心煩舌径の比率を, 煩舌径近遠
心示数によってみると，上下顎とも第 1 加ら第 2 , 第 3 大曰霜へと示数值が順次小さくなっていることからも， 煩舌径の遠心部が後方歯程縮小していることが判る。し かし，このことは上䫕の方が著しい，馬場 $(1979)^{10)}$ は 縮小示数というものをニホンザルにおいて提示している が，著者もてれにならってマカク属の 3 璉について示数 值を算出してみた，その結果，上龥第 1 大臼歯では二木 ンザル6.76, は馬場と大差はなく, カニクイザルの7.81, は同にく佐伯 $(1961)^{3)}$ の 5.54 よりも大きい. これらの 值は広鼻猿類に比べて大きく，また類人猿よりもやや大 きい数值を示しており，マカク属は菌冠の遠心煩舌径が 他の畫長類よりも縮小していることがうかがえる．下顎 第 1 大曰歯では上額に比べて縮小示数は小さく，特に二 ホンザルでは示数值 0 で, 他の大部分の狭鼻猿類では負 の值を示しているものが多い．但し，カニクイザルにお いては 5.36 と, 霊長類の中でも最も大きい数值を示して いた．上䋶第 2 大曰歯は縮小示数が増大し，アカゲザ ル，カニクイザル，二ホンザルともに10.3〜10.8を示 し, 第 3 大曰雬では更に增大し, 特に二ホンザルで著し

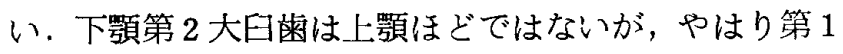
大曰歯よりも縮小示数は増大し，特にマカク属で著明で ある．また第 3 大曰菊では更に增大しているが，カニク イザルは第 1 より第 2 ，第 3 大臼菌といずれる同じよう にマカク属の中では最大の数值を示していた.

4 第 1 大田歯汶対する第 2 および第 3 大曰歯の大き さの関係

上下䅡の第 1 大臼曾を基準にして，第 2 および第 3 大 田歯の各部の大きさの割合を大田歯示数として算出し た．すなわち，ヒトの場合は藤田 $(1956)^{20}$ や尾崎（19

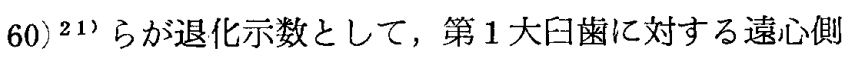
の蒾の縮小退化の度合を表わしたものとほぼ同じもので ある. サルの場合はヒトと違って，遠心側の柬は必ずし も縮小してはおらず，大きくなっている㑯向にあるの で，退化示数という言葉は使わなかった。

第 1 大日崡に対する第 2 大曰歯の示数值では, 上顎に おいては近遠心徍, 煩舌径, 咬合面面積ともに第 2 大臼 圃がきいととを示しており，特に二ホンザルが他の二 者よりも示数值が大きい。乙れは馬場 ${ }^{101}$ や佐伯ら ${ }^{21}$ の ニホンザルとほぼ同じで，その他のマカク属に比べても 大きい示数值であった.一方, チンパンジーでは示数值 はほほ 100 で，第 1 と第 2 大臼歯は大きさに差異はない ようである．またヒトでは 100 以下の数值で第 2 大曰歯 が第 1 大臼歯よりも明らかに縮小している．下顎におい てもマカク属に扔ては上領と同椂の傾向が認められる 
が，チンパンジーやヒトでは上顩ほどに第 2 大曰歯の䌈 小傾向は諗められず，第 1 と第 2 大曰菌はほぼ同じ程度 の大きさである.

次に第 1 大曰歯に対する第 3 大曰藏の大曰歯示数であ るが，上顎においては各計測值とも著者の二ホンザルは カニクイザルよりも大きい数值を示し，乙れらの值は馬 場 ${ }^{0}$ や佐伯ら 2 の二ホンザル，中川(16)のカニクイザルと 大差はなく, 他のマカろ属も同じように 100 以上の数值 を示して第 1 上りも第 3 大臼歯の大きいてとを示唆して いる。但し，第 1 大臼歯より第 2 大臼歯への増大に比 へ，第 2 大曰菊から第 3 大曰㐘への増大はほとんどみら れず，なかでもカニクイザルではむしろ第 3 大臼歯にお いては縮小化の傾问が琶められた。このととは他のマカ ク属にも認められる傾向であり，チンパンジ一，ヒトに おいては尚一㬝著明に認められる現象である。すなわ ち，マカク属の上顩大曰䨑においては第 1 大曰雪より第 2 大曰歯，第 3 大曰歯へと順次分化が進み，ついで今度 は第 3 大曰歯より退化が始まっていることを暗示してい るもの之考えられる。

下顎においては，第 1 大曰歯に対して第 3 大臼歯は第 2 大曰歯に対するより以上に，その示数値が大きく，遠 心側の粜になるほど，その大きさを増大している。てれ は下類ではまだ第 2 ，第 3 大臼歯が分化の段階にあっ て，退化的現象を現わすに至っていないととを示してい るものと考えられる。しかし，チンパンジーやヒトでは 第 3 大目歯はすでに縮小化の傾问仙あるといえる．すな わち，マカク属の場合，上顎大臼雬が下顎大曰柬よりも 進化が先行していると考えられる。

\section{結 論}

霊長類の中で, 狭鼻猿類のマカク属について，上下顎 大臼雪の歯冠の計測を行ったが, 今回使用したのは当教 室所蔵のアカゲザル，ニホンザルおよびカニクイザルの 3 種で, こ机らの調査結果を他の霊長類と比較し, 種々 なる観点から検討を行った。その結果は以下のごとくで ある。
1 上下顎の第 1 大臼歯の歯冠の近遠心径，煩舌径お よび咬合面面積はニホンザルがカニクイザルおよびアカ ゲザルに比べて著しく大きく，後の二種間にはそれ程大 きな差は認められなかった。また第 2 大臼菊抢よび第 3 大曰歯においても，第 1 大目霜とほぼ同様の傾向を示し ていた。

2 マカク属の柬の大きさは, 霊長類の中では, 他の 狭鼻猿類のグループと同じ範疇にあり，広鼻猿類よりも 大きく, ヒト科よりも小さい。

3 マカク属の歯冠示数は上下顎の各大曰霜ともにす べて 100 以上の数值を示し, 煩舌径よりも近遠心径が優 っている．特に下頡に扔てては上䫚よりも著しく近遠心 径が長い，一般に狭鼻猿類は広鼻猿類や七ト科に比べて 大きい示数值を示しており，特に上顎においては狭鼻猿 類之は反対に厸鼻猿類や七卜科のほとんどの種属が 100 以下の数值で，煩舌径が近遠心径よりも大である.

4 歯冠の近心煩舌径と遠心煩舌径の差を歯冠遠心側 縮小示数によってみると，一般に近心側が遠心側よりも 優って抢り，上顎が下顎よりも遠心側の縮小率が著し い.また第 1 大曰歯よりも第 2 大臼歯，第 3 大臼菌へと 後方の歯ほど遠心側の縮小率は增大している．マ办属 の縮小示数は他の霊長類に比べると大差はないが，僅か にマカク属が大きい傾向にあるようである．

5 マカク属污いては第 1 大臼䨑に対して，第 2 大 田柬抢よび第 3 大臼雨はその大きさ增している。しか

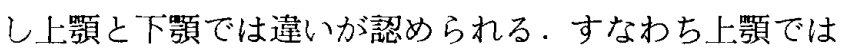
第 1 大田菌より第 2 大田菌へと大きくなっているが，第 3 大田歯注第 2 大臼歯とほとんど差はなく，カニクイザ

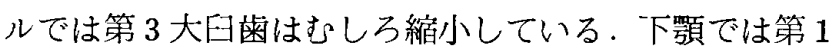
大曰歯より第 2 ，第 3 大曰歯へと順次增大している。

6 マカク属が第 1 大目䨑よりも遠心側の菌が大きく なっているのに比へ，類人猿やヒトでは逆に遠心側の蒾 ほど縮小化の傾向にあり，特にヒトに扔いて著しい，す なわちヒト科では大曰歯の遠心側からの退化現象がみら れるのに対し，マカク属では未だそのような現象は認め られないことを示している。

\section{引用 文 献}

1) Remane, A. : Die Entstehung der Bilophodontie bei den Cercopithecidae. Anat. Anz. 98:161165,1951 .

2）佐伯政友・田代寛一郎・葉山杉夫：猿の歯の形態学的研究 (1)大曰歯歯冠の形熊. 口病誌 $28: 81-97$, 1961.

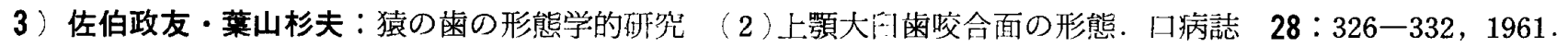


4 ) Frisch, J.E. : Sex-differences in the canines of the Gibbon (Hylobates lar). Primates 4:1-10, 1963 .

5 ) Saheki, M. : Morphological studies of Macaca fuscata. IV . Dentition. Primates 7:407-421, 1966.

6 ）中川三省：カニクイザル (Macaca irus) の歯科学的研究. 九州歯会誌 $24: 735-758,1971$.

7 ) Lauer, C. : A comparison of sexual dimorphism and range of variation in Papio cynocephalus and Gorilla gorilla dentition. Primates $16: 1-7,1975$.

8 ) 瀬戸口烈司：ホエザルの祖先の中新世のスタートニアに性的二型は認められるか. 季刊人類学 $13(2): 3$ $-33,1982$.

9 ) 瀬戸口烈司：リスザルの歯列にみられる性的二型. 季刊人類学 14(1):29-49, 1983.

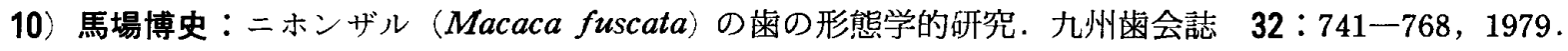

11）花田通成：アカゲザル（Macaca mulatta）の乳菊形態について. 九州雪会誌 $33: 351-366,1979$.

12）河井雅雄・岩本光雄・吉場健二：世界のサル．毎日新聞社，東京，1968，1-237.

13）藤田恒太郎：歯の計測規準について. 人類誌 $61: 27-32,1949$.

14）茂原信生：人類学講座 2 . 霊長類, 雄山閣, 東京, $1977,116-130$.

15) Clark, G.: The antecedents of man, an introduction to the evolution of the Primates. Quadrangle Books, Chicago, 1960,75-125.

16) Swindler, D. : Dentition of living primates. Academic Press, London, 1976, 116-299.

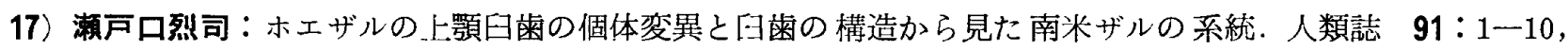
1983.

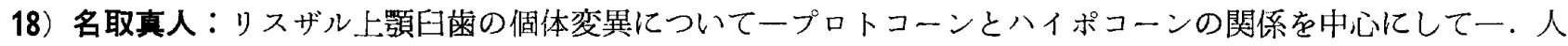
類誌 $91: 187-198,1983$.

19）藤田恒太郎・桐野忠大：畨の解剖学, 金原出版, 東京, $1976,27-88$.

20）藤田恒太郎：歯の退化指数について. 解剖誌 $25: 196,1950$.

21）尾崎 公:日本人の雪の退化示数. 解剖誌 $35: 563-577,1960$. 